\title{
Factors controlling decomposition of soil organic matter in fallow systems of the high tropical Andes: A field simulation approach using ${ }^{14} \mathrm{C}$ - and ${ }^{15} \mathrm{~N}$-labelled plant material
}

\author{
Pierre Bottner $^{\mathrm{a}}$, Marc Pansu ${ }^{\mathrm{b}, *}$, Lina Sarmiento ${ }^{\mathrm{c}}$, Dominique Hervéb \\ Ruben Callisaya-Bautista ${ }^{\mathrm{d}}$, Klaas Metselaar ${ }^{\mathrm{e}}$ \\ ${ }^{a}$ CEFE-CNRS, 1919 Route de Mende 34293, Montpellier, Cedex 05, France \\ ${ }^{\mathrm{b}} I R D, B P$ 64501, 34394 Montpellier, Cedex 05, France \\ ${ }^{\mathrm{C}}$ ICAE Facultad de Ciencias, Universidad de Los Andes, Merida 5101, Venezuela \\ IBTEN, Avenida de Agosto, 2905 La Paz, Bolivia \\ ${ }^{\mathrm{e}} \mathrm{PRI}$, Wageningen, The Netherlands
}

Received 3 June 2005; received in revised form 20 January 2006; accepted 28 January 2006

Available online 18 April 2006

\begin{abstract}
$\mathrm{N}$-rich $(\mathrm{C}: \mathrm{N}=27)$ and $\mathrm{N}$-poor $(\mathrm{C}: \mathrm{N}=130)$ wheat straw, labelled with ${ }^{14} \mathrm{C}$ and ${ }^{15} \mathrm{~N}$, was incubated for 2 yr in two major ecosystems of the upper elevation belt of cultivation in the high Andes: the moist Paramo (precipitation $=1329 \mathrm{~mm}$, altitude $=3400 \mathrm{~m}$ asl, Andes of Merida, Venezuela) and the dry Puna (precipitation $=370 \mathrm{~mm}$, altitude $=3800 \mathrm{~m}$ asl, Central Altiplano, Bolivia). The experiment was installed in young $(2 \mathrm{yr})$ and old ( $7 \mathrm{yr})$ fallow plots. The following soil analyses were performed at nine sampling occasions: soil moisture, total- ${ }^{14} \mathrm{C}$ and $-{ }^{15} \mathrm{~N}$, and Microbial Biomass (MB)- ${ }^{14} \mathrm{C}$ and $-{ }^{15} \mathrm{~N}$. The measured data were fitted by the MOMOS-6 model (a process based model, with five compartments: labile and stable plant material, MB, and labile (HL) and stable humus (HS)) coupled with the SAHEL model (soil moisture prediction) using daily measured and/or predicted meteorological data. The aim was to understand how (1) the climatic conditions, (2) the quality of plant material, (3) the fallow age and (4) the soil properties affect the cycling of $\mathrm{C}$ and $\mathrm{N}$ within the soil organic matter system.

The fallow age $(2$ and $7 \mathrm{yr})$ did not affect the measured data or the model predictions, indicating that in these systems the decomposition potential is not affected by fallow length. During the short initial active decomposition phase, the labile plant material was quickly exhausted, enabling a build up of MB and of HL. During the low activity phase, that covered 4/5 of the time of exposure, the MB size decreased slowly and the HL pool was progressively exhausted as it was reused by the MB as substrate. The HL compartment was directly or indirectly the major source for the inorganic ${ }^{15} \mathrm{~N}$ production. If the $\mathrm{C}: \mathrm{N}$ ratio of the added plant material increased, the model predicted (1) a reduction of the decomposition rates of the plant material (essentially the stable plant material) and (2) an increased mortality of the MB which increased the production of HL (microbial cadavers and metabolites). Thus the essential effect of the slower decomposition due to the $\mathrm{N}$-poor plant material was a higher accumulation of $\mathrm{C}$ and $\mathrm{N}$ in the HL and its slower recycling by the MB during the low activity phase. The labelling experiment allows to understand the higher soil native organic matter content in Paramo soils compared to Puna. The large sequestration of organic matter generally observed in the Paramo soils can be explained by two abiotic factors: the unfavourable soil microstructure and the accumulation of free aluminium linked to the climatic and acid soil conditions, inhibiting the microbial activity physically and chemically.
\end{abstract}

(C) 2006 Elsevier Ltd. All rights reserved.

Keywords: Soil organic matter; Decomposition; Carbon; Nitrogen; Modelling; Limiting factors; ${ }^{14} \mathrm{C}$; ${ }^{15} \mathrm{~N}$; Fallow; Andes

${ }^{*}$ Corresponding author. Tel.: + 334674 16228; fax: + 33467416294 .

E-mail address: pansu@mpl.ird.fr (M. Pansu).

\section{Introduction}

In the tropical Andes, the altitudinal belt above the continuous timberline, between 3300 and $4800 \mathrm{~m}$ asl under 
moist conditions of the Northern part is covered by the Paramo, an alpine ecosystem (Venezuela, Columbia and Ecuador), and under dry conditions of the central Andes by the Puna, a semi-desertic ecosystem (Peru and Bolivia). Both areas represent the upper elevation belt of agricultural cultivation with crop rotations including short crop (1-3 yr) and long fallow (5-10 yr).

The wet Paramo is characterised by soils rich in organic matter, reducing the rate of erosion despite cultivation areas located on steep slopes (Llambi and Sarmiento, 1998; Sarmiento, 2000; Abadín et al., 2002; Poulenard et al., 2003). Conservation management is fundamental in these mountains, as they constitute the headwater areas of catchments and as degradation would have negative effects downriver, where large human settlements are located. These high tropical mountain ecosystems with an exceptionally large biodiversity are the only tropical systems subjected to cryothermic stress. The long fallow period allows soil restoration, control of crop diseases, extensive grazing, fuel wood and medicinal plant collection. The dry Puna is characterised by a very low organic matter content, a higher sensitivity to erosion, but this type of agriculture is the basis of the subsistence for a large rural population mainly in the Central Andes (Altiplano).

At present, Paramo and Puna are subjected to accelerated transformations with intensified cultivation and continuous expansion of the fallow agriculture frontier (Hofstede et al., 2002). The intensification of land use raises the question of dynamics of the soil organic matter (SOM) and consequences on soil stability and soil erosion. Under the moist conditions of Paramo, the soil carbon content is up to $10 \%$ and SOM seems to be the main factor determining the soil physical properties and erosion sensitivity. Under the drier conditions of Puna the $\mathrm{C}$ content is less than $1 \%$ and SOM is a small (but the only) reservoir regulating nutrient cycling. The much higher SOM content in Paramo, despite more favourable climatic decomposition conditions, cannot entirely be explained by the difference in plant biomass and residues production between Paramo and Puna (Martineau, pers. comm.: FAPROM model; Martineau and Saugier, 2006a, b). Thus the question is to understand the SOM sequestration in the Paramo soils. Which are the factors limiting decomposition? The Paramo soils contain up to $45 \mathrm{~kg}$ organic $\mathrm{Cm}^{-2}$ distributed over $50 \mathrm{~cm}$ depth (Poulenard et al., 2003); the contribution of the reservoir at a regional scale to the global carbon balance is another reason to improve our understanding of the Paramo system.

The external climatic conditions acting specifically on ecosystem productivity and decomposition are often not sufficient to explain the accumulation of SOM. Among the classical biotic factors defining the quality of the plant residues (nutrient content and availability, $\mathrm{C}: \mathrm{N}$ ratio, lignin content and N:lignin ratio, etc.), Schimel and Weintraub (2003) recently highlighted the role of the labile plant material that provides microorganisms with energy for exoenzyme activity allowing the decomposition of recalcitrant material. The soil intrinsic abiotic factors, defining the physical and chemical soil properties, determine (through microstructure and aggregate stability) the soil microenvironment and substrate accessibility. The relative importance of each factor may differ among the microbial functional groups and succession of organisms in the time scales (Norton and Firestone, 1996).

In the present work, ${ }^{14} \mathrm{C}$ - and ${ }^{15} \mathrm{~N}$-labelled wheat straw, with two contrasting $\mathrm{N}$ contents, were incubated for $2 \mathrm{yr}$ in young and old fallow plots of the wet Venezuelan Paramo and of the dry Bolivian Puna. The measured data was fitted by a process-based model. The aim was to understand how (1) the $\mathrm{N}$ content of the plant material, (2) the fallow age, (3) the climatic conditions and (4) the abiotic soil properties affect the transfers of $\mathrm{C}$ and $\mathrm{N}$ within the SOM system.

\section{Materials and methods}

\subsection{Site descriptions}

The experiment was installed in two contrasting climatic zones in the latitudinal belt above the continuous timberline of the Andean mountains (Table 1):

(1) Under wet conditions, at the Paramo site of Gavidia (Ga treatments in Table 2, Northern Andes of Merida, Venezuela). The mean annual temperature is $8.5^{\circ} \mathrm{C}$, with very low seasonal variations (between 7 and $11^{\circ} \mathrm{C}$ ). The mean annual precipitation is $1329 \mathrm{~mm}$. The soil is deep, clay-loamy, stony and with a high organic matter content. The structure is fluffy (dry soil) and massive (wet soil). The acidity induces a high content of exchangeable Aluminium and free Al. The cultivation system is based on a long grazing fallow period alternating with a short crop period.

(2) Under arid conditions, in the Puna site of Patacamaya (Pa treatments in Table 2, Central Andes, Bolivian Altiplano). During the $2 \mathrm{yr}$ of experiment, the annual mean temperature was $8.7^{\circ} \mathrm{C}$, i.e. similar to the Paramo site, but with a high seasonal amplitude (between 1 and $14^{\circ} \mathrm{C}$ ). The mean annual precipitation was $370 \mathrm{~mm}$. The soil is shallow, sandy, stony and with a very low organic matter content. The structure is particulate. At $\mathrm{pH}$ 6.6, the content of exchangeable and free $\mathrm{Al}$ are negligible. As in the wet Paramo, the cultivation system is based on long fallow periods with grazing and short crop periods.

Thus the sites, representative of two major Andean zones of the upper belt of cultivation, differ markedly by the climatic conditions (specially moisture regime, Fig. 2) as well as by the soil characteristics, which are closely related to climate conditions: both sites are developed on acid rock material. The wetter conditions at Gavidia induce (1) a higher soil acidity, with production of free and exchangeable Al by weathering and (2) a markedly higher organic 
Table 1

Mean characteristics of the Gavidia and Patacamaya sites

\begin{tabular}{|c|c|c|}
\hline Sites & Gavidia (Venezuela) & $\begin{array}{l}\text { Patacamaya } \\
\text { (Bolivia) }\end{array}$ \\
\hline Localization & $\begin{array}{l}\text { Sierra Nevada National Park } \\
\text { Merida }\end{array}$ & Central Altiplano \\
\hline Coordinates & $8^{\circ} 40^{\prime} \mathrm{N} ; 70^{\circ} 55^{\prime} \mathrm{W}$ & $17^{\circ} 15^{\prime} \mathrm{S} ; 67^{\circ} 57^{\prime} \mathrm{W}$ \\
\hline Altitude asl & $3400 \mathrm{~m}$ & $3789 \mathrm{~m}$ \\
\hline Cropping system & $\begin{array}{l}\text { Long grazing fallow periods } \\
(7-10 \mathrm{yr}) \text { alternating with } \\
\text { short }(2 \mathrm{yr}) \text { potatoes and } \\
\text { cereals crop periods }\end{array}$ & $\begin{array}{l}\text { Long grazing fallow } \\
\text { periods }(7-8 \mathrm{yr}) \\
\text { alternating with } \\
\text { short }(2-3 \mathrm{yr}) \\
\text { potatoes, cereals or } \\
\text { quinoa crop periods }\end{array}$ \\
\hline Precipitation (mm) & 1329 & 370 \\
\hline $\begin{array}{l}\mathrm{T} \text { mean (average, } \\
\left.{ }^{\circ} \mathrm{C}\right)\end{array}$ & 8.5 & 8.7 \\
\hline $\mathrm{T} \min \left(\right.$ average $\left.{ }^{\circ} \mathrm{C}\right)$ & 5 & 0.2 \\
\hline $\mathrm{T} \max$ (average ${ }^{\circ} \mathrm{C}$ ) & 9 & 17.2 \\
\hline $\begin{array}{l}\text { Soil name (USA } \\
\text { soil taxonomy) }\end{array}$ & Humitropept & Haplic xerosol \\
\hline Soil depth (cm) & 70 & 30 \\
\hline $\begin{array}{l}\text { Stoniness }(0-10 \mathrm{~cm} \\
\text { layer, } \mathrm{v} / \mathrm{v})\end{array}$ & $0.26 \pm 0.07$ & $0.20 \pm 0.14$ \\
\hline Soil structure & $\begin{array}{l}\text { Fluffy (dry) and massive } \\
\text { (moist) }\end{array}$ & Particulate \\
\hline Soil texture & Clay-loamy, stony & Sandy, stony \\
\hline Sand $(\%)$ & $54 \pm 4$ & $79 \pm 8$ \\
\hline Silt $(\%)$ & $31 \pm 1$ & $15 \pm 4$ \\
\hline Clay $(\%)$ & $15 \pm 5$ & $6 \pm 1$ \\
\hline $\mathrm{pH}\left(\mathrm{H}_{2} \mathrm{O}\right)$ & $4.5 \pm 0.2$ & $6.6 \pm 0.4$ \\
\hline $\mathrm{C}(\%)$ & $9.9 \pm 0.8$ & $0.5 \pm 0.2$ \\
\hline $\mathrm{N}(\%)$ & $0.65 \pm 0.15$ & $0.06 \pm 0.03$ \\
\hline $\mathrm{C}: \mathrm{N}$ ratio & $15.3 \pm 3.7$ & $7.6 \pm 4.9$ \\
\hline $\begin{array}{l}\text { Exchangeable } \\
\text { aluminium } \\
\left(\mathrm{cmol} \mathrm{kg}^{-1}\right)\end{array}$ & $11.0 \pm 2.2$ & Negligible (pH 6.6) \\
\hline $\begin{array}{l}\text { Free aluminium } \\
\left(\mathrm{g} \mathrm{kg}^{-1}\right)\end{array}$ & $25.5 \pm 6.0$ & Negligible (pH 6.6) \\
\hline $\begin{array}{l}\text { MCFC (volumetric } \\
\text { moisture content at } \\
\text { field capacity) }\end{array}$ & $0.52 \pm 0.04$ & $0.35 \pm 0.04$ \\
\hline $\begin{array}{l}\text { MCWP (volumetric } \\
\text { moisture content at } \\
\text { wilting point) }\end{array}$ & $0.28 \pm 0.01$ & $0.06 \pm 0.01$ \\
\hline
\end{tabular}

matter content generating a higher water retention at field capacity and at wilting point (Table 1). The sites also differ by the soil texture; this characteristic is independent from climate.

In both sites, the experiment was installed in (1) a plot lying fallow for $2 \mathrm{yr}$ (referred to as "young" (Y); GaY and $\mathrm{PaY}$ treatments in Table 2) with mainly herbaceous vegetation and (2) in a plot lying fallow for $7 \mathrm{yr}$ (referred to as "old" $(\mathrm{O}) ; \mathrm{GaO}$ and $\mathrm{PaO}$ treatments) covered, in addition to herbaceous plants, by shrubs in the Puna (height $=0.5-1 \mathrm{~m}$ ) and shrubs and giant rosettes in the Paramo (height $=1-1.5 \mathrm{~m}$ ). The soil cover is presented in Table 2).

\subsection{Site treatments}

An old cultivar of spring wheat (Florence Aurore) with a low nitrogen requirement was grown from seed to maturity in a labelling chamber $(l=120 \mathrm{~cm}, w=90 \mathrm{~cm}, h=90 \mathrm{~cm})$ in controlled conditions of ${ }^{14} \mathrm{CO}_{2}$ atmosphere $\left(\mathrm{CO}_{2}=0.03 \% \mathrm{v} / \mathrm{v}\right.$, radioactivity $\left.=0.86 \mathrm{kBq} \mathrm{mg}^{-1} \mathrm{C}\right)$, temperature $\left(16 \mathrm{~h} 24^{\circ} \mathrm{C}\right.$ day temperature and $8 \mathrm{~h} 15^{\circ} \mathrm{C}$ night temperature) and radiation. The plants, cultivated in pure sand, were periodically (every $6 \mathrm{~h}$, during $30 \mathrm{~min}$ ) flooded with a complete nutrient solution (containing per litre: $\left(12 \mathrm{ml} \quad \mathrm{Ca}\left({ }^{15} \mathrm{NO}_{3}\right)_{2} \cdot 4 \mathrm{H}_{2} \mathrm{O} \quad 1 \mathrm{~mol} \mathrm{~L}^{-1}\right)+\left(4.5 \mathrm{ml} \quad \mathrm{KH}_{2} \mathrm{PO}_{4}\right.$ $\left.1 \mathrm{~mol} \mathrm{~L}^{-1}\right)+\left(4.5 \mathrm{ml} \mathrm{MgSO}_{4} 1 \mathrm{~mol} \mathrm{~L}^{-1}\right)+$ micronutrients $)$. $\mathrm{Ca}\left({ }^{15} \mathrm{NO}_{3}\right)_{2}$ was the sole $\mathrm{N}$ source. At harvest, the wheat was dried at $40{ }^{\circ} \mathrm{C}$. Only the stems and leaves were used in the experiment. They were milled in coarse $(2-7 \mathrm{~mm}$ long) particles and well mixed. Two kinds of straw were used (Table 3): (1) an $\mathrm{N}$-rich material (C:N $=26.8$; referred to as treatment $\mathrm{N}+$ in Table 2), grown at the normal concentration of nutrients and harvested at the beginning of the ear maturation. (the ${ }^{15} \mathrm{~N}$ atom $\%$ of the nutrient solution used for the $\mathrm{N}+$ straw was 10) and (2) an $\mathrm{N}$-poor material ( $\mathrm{C}: \mathrm{N}=130$; referred to as treatment $\mathrm{N}-$ in Table 2), grown at one-fifth of the normal nutrient solution concentration $\left({ }^{15} \mathrm{~N}\right.$ atom $\left.\%=24\right)$ and harvested at complete ear maturity ( 7 days after the $\mathrm{N}$-rich straw). The biochemical (van Soest et al., 1991), isotopic and quality (according to Thuriès et al., 2002) characteristics of the two kinds of plant material are presented in Table 3 .

\subsection{Field exposure}

In each site the $\mathrm{N}+$ material was incubated in both the young and the old fallow plots; the $\mathrm{N}-$ material was incubated in the old fallow plot only. Table 2 summarises the different treatments: at Gavidia, GaYN,$+ \mathrm{GaON}+$ and $\mathrm{GaON}-$ and at Patacamaya, $\mathrm{PaYN}+, \mathrm{PaON}+$ and $\mathrm{PaON}-$. For each treatment, homogenised air-dry soil, sampled from the $5-10 \mathrm{~cm}$ layer, was divided in 40 samples of $150.0 \mathrm{~g}$ soil (except for $\mathrm{GaON}-: 180.0 \mathrm{~g}$ ). Table 2 shows the amount of labelled straw that was homogeneously added to each sample, the straw weight per gram soil, the straw-C (= labelled $\mathrm{C})$ in \% of total-C and straw-N $(=$ labelled $\mathrm{N})$ in $\%$ of total-N. The soil-straw mixture was placed in $10 \times 8 \mathrm{~cm}$ sealed polyester bags made from $1 \mathrm{~mm}$ mesh tissue (to allow roots to penetrate) at the upper side and $0.5 \mathrm{~mm}$ mesh tissue (to prevent loss of material at sampling) at the lower side. The bags were horizontally placed back into the $5-10 \mathrm{~cm}$ layer and were covered with the $0-5 \mathrm{~cm}$ top layer (set apart). As the $0-5 \mathrm{~cm}$ and $5-10 \mathrm{~cm}$ layers had been air dried, they were brought to field capacity by sprinkling after installation of the experiment. The experiment lasted over $2 \mathrm{yr}$. Over this period, 9 samplings +1 initial sampling were performed, using at each sampling time four replicates for each treatment. 
Table 2

Treatments and characteristics of the plots

\begin{tabular}{|c|c|c|c|c|c|c|}
\hline \multirow[t]{2}{*}{ Sites } & \multicolumn{3}{|c|}{ Gavidia (Venezuela) } & \multicolumn{3}{|c|}{ Patacamaya (Bolivia) } \\
\hline & Young fallow & \multicolumn{2}{|l|}{ Old fallow } & Young fallow & \multicolumn{2}{|l|}{ Old fallow } \\
\hline Fallow age (yr) & 1 (a) & \multicolumn{2}{|l|}{7 (b) } & 1 (a) & \multicolumn{2}{|l|}{7 (b) } \\
\hline Soil cover by natural vegetation $\mathrm{s} / \mathrm{s}$ & 0.85 & \multicolumn{2}{|l|}{0.9} & 0.2 & \multicolumn{2}{|l|}{0.4} \\
\hline \multicolumn{7}{|l|}{ Soil native organic matter } \\
\hline Soil native $\mathrm{C}(\%) ; n=8$ & $9.42 \pm 0.14$ & \multicolumn{2}{|l|}{$8.81 \pm 0.06$} & $0.45 \pm 0.02$ & \multicolumn{2}{|l|}{$0.55 \pm 0.02$} \\
\hline Soil native $\mathrm{N}(\%) ; n=8$ & $0.55 \pm 0.06$ & \multicolumn{2}{|l|}{$0.56 \pm 0.02$} & $0.08 \pm 0.005$ & \multicolumn{2}{|l|}{$0.09 \pm 0.01$} \\
\hline Soil native $\mathrm{C} / \mathrm{N}$ & $17.1^{-}$ & \multicolumn{2}{|l|}{15.8} & 5.6 & \multicolumn{2}{|l|}{6.3} \\
\hline \multirow[t]{2}{*}{ Treatments } & $\begin{array}{l}\mathrm{N}+\text { straw } \\
=\mathrm{Ga} \mathrm{Y} \mathrm{N}+\end{array}$ & $\begin{array}{l}\mathrm{N}+\text { straw } \\
=\mathrm{GaON}+\end{array}$ & $\begin{array}{l}\mathrm{N}-\text { straw } \\
=\mathrm{GaON}-\end{array}$ & $\begin{array}{l}\mathrm{N}+\text { straw } \\
=\mathrm{Pa} \mathrm{Y} \mathrm{N}+\end{array}$ & $\begin{array}{l}\mathrm{N}+\text { straw } \\
=\mathrm{PaON}+\end{array}$ & $\begin{array}{l}\mathrm{N}-\text { straw } \\
=\mathrm{PaO} \mathrm{N}-\end{array}$ \\
\hline & \multicolumn{2}{|c|}{$=\mathrm{Ga} \mathrm{N}+$} & $=\mathrm{Ga} \mathrm{N}-$ & \multicolumn{2}{|c|}{$=\mathrm{Pa} \mathrm{N}+$} & $=\mathrm{Pa} \mathrm{N}-$ \\
\hline Duration of the experiment & \multicolumn{3}{|c|}{ From $13 / 11 / 1998$ to $10 / 11 / 2000$} & \multicolumn{3}{|c|}{ From $29 / 11 / 1998$ to $27 / 11 / 2000$} \\
\hline Dry soil in each bag (g) & 150 & 150 & 180 & 150 & 150 & 150 \\
\hline Weight of straw added to each bag (g straw per sample) & 3.26 & & 3.90 & 0.347 & & 0.646 \\
\hline Weight of straw added: mg straw g-1 dry soil & 21.7 & 21.7 & 21.7 & 2.3 & 2.3 & 4.3 \\
\hline Added straw-C in $\%$ of total (soil + straw) $\mathrm{C}$ & 9.0 & 9.6 & 9.9 & 18.1 & 15.3 & 26.0 \\
\hline Added straw- $\mathrm{N}$ in $\%$ of total (soil + straw) $\mathrm{N}$ & 5.9 & 5.8 & 1.2 & 4.4 & 4.0 & 1.5 \\
\hline Measured initial ${ }^{15} \mathrm{~N}$ enrichment of the soil $(\%) ; n=8$ & $0.527 \pm 0.024$ & $0.512 \pm 0.026$ & $0.262 \pm 0.002$ & $0.527 \pm 0.033$ & $0.444 \pm 0.019$ & $0.427 \pm 0.017$ \\
\hline Lowest measured ${ }^{15} \mathrm{~N}$ enrichment $(\%) ; n=8$ & $0.369 \pm 0.008$ & $0.354 \pm 0.010$ & $0.217 \pm 0.010$ & $0.212 \pm 0.023$ & $0.204 \pm 0.018$ & $0.224 \pm 0.043$ \\
\hline Soil natural ${ }^{15} \mathrm{~N}$ isotopic ratio $(\%) ; n=12$ & $0.367 \pm 0.0001$ & $0.367 \pm 0.0002$ & & $0.373 \pm 0.001$ & $0.371 \pm 0.001$ & \\
\hline
\end{tabular}

(a) Dominated by forbs; (b) dominated by woody plants; $\mathrm{Ga}=$ Gavidia; $\mathrm{Pa}=$ Patacamaya; $\mathrm{Y}$ and $\mathrm{O}=$ young and old fallow; $\mathrm{N}+=\mathrm{N}$ rich straw; $\mathrm{N}-=\mathrm{N}$ poor straw; errors are standard deviations.

Table 3

Characteristics of the $\mathrm{N}$ rich $(\mathrm{N}+)$ and $\mathrm{N}$ poor $(\mathrm{N}-)$ straw (stem$\mathrm{s}+$ leaves)

\begin{tabular}{|c|c|c|c|c|c|}
\hline \multirow{2}{*}{$\begin{array}{l}\mathrm{N} \text { rich }(\mathrm{N}+) \text { and } \mathrm{N} \text { poor } \\
(\mathrm{N}-) \text { straws }\end{array}$} & \multicolumn{2}{|c|}{$\mathrm{N}$ rich $(\mathrm{N}+)$} & \multicolumn{2}{|c|}{$N$ poor $(N-)$} & \multirow[t]{2}{*}{$n$} \\
\hline & & $\mathrm{SD}$ & & $\mathrm{SD}$ & \\
\hline $\mathrm{C} \%$ & 43.0 & 0.4 & 44.9 & 0.14 & 8 \\
\hline $\mathrm{N} \%$ & 1.60 & 0.05 & 0.35 & 0.01 & 8 \\
\hline $\mathrm{C}: \mathrm{N}$ & 26.8 & 0.8 & 130.1 & 5.3 & \\
\hline $\begin{array}{l}\text { Solubles compounds }(\%) \\
\text { (1) }\end{array}$ & 36.1 & 0.5 & 17.3 & 0.6 & 6 \\
\hline Hemicelloses (\%) (1) & 25.2 & 0.6 & 28.1 & 0.6 & 6 \\
\hline Cellulose $(\%)(1)$ & 26.0 & 0.6 & 41.7 & 0.8 & 4 \\
\hline Lignin $(\%)(1)$ & 3.0 & 0.2 & 6.4 & 0.2 & 2 \\
\hline Ashes $(\%)(1)$ & 9.6 & 0.2 & 6.5 & 0.2 & 6 \\
\hline $\begin{array}{l}{ }^{15} \mathrm{~N} \text { isotopic enrichment of } \\
\text { the straw }(\%)\end{array}$ & 9.88 & 0.25 & 22.56 & 0.28 & 6 \\
\hline $\begin{array}{l}{ }^{14} \mathrm{C} \text { activity of the straw } \\
\left(\mathrm{Bq} \mathrm{mg}^{-1} \mathrm{C}\right)\end{array}$ & 598 & 16 & 694 & 10 & 8 \\
\hline $\begin{array}{l}\text { Labile }{ }^{14} \mathrm{C} \% \text { total- }{ }^{14} \mathrm{C} \text { of } \\
\text { plant material (2) }\end{array}$ & 89.3 & & 85.6 & & \\
\hline
\end{tabular}

$\mathrm{SD}=$ Standard deviation; $\mathrm{n}=$ number of analyses; (1) van Soest et al. (1991); (2) according to equations of Thuriès et al. (2002).

\subsection{Analyses}

At sampling, the moist soil in each bag was homogenised and $3 \times 5 \mathrm{~g}$ soil was dried at $105^{\circ} \mathrm{C}$ for moisture measurement.
At Gavidia the remainder of the moist soil was subsampled for analyses (1) of microbial biomass (MB) $-{ }^{14} \mathrm{C}$ (4 field replicates $\times 2$ analysis replicates), $-\mathrm{N}$ and $-{ }^{15} \mathrm{~N}$ (4 field replicates), and of (2) soil total-C, and $-{ }^{14} \mathrm{C}(4 \times 8$ replicates $)$ and soil total-N and $-{ }^{15} \mathrm{~N}(4 \times 2$ replicates). $\mathrm{MB}$ was measured according the fumigationextraction method of Brookes et al. (1985), using $20 \mathrm{~g}$ soil and $150 \mathrm{ml}$ extractant of $\mathrm{K}_{2} \mathrm{SO}_{4} 0.5 \mathrm{~mol} \mathrm{~L}^{-1} ;{ }^{14} \mathrm{C}$ was measured on the extracts using liquid scintillation counting (Tricarb 1500, Packard), $\mathrm{N}$ and ${ }^{15} \mathrm{~N}$ was measured using the Kjeldahl procedure and coupled $\mathrm{CHN} /$ mass spectrometry (Finnigan delta S); $k_{\mathrm{EC}}$. (MB-C correcting factor $)=0.45 \quad$ (Joergensen, 1996), $k_{\mathrm{EN}} \quad(\mathrm{N}$ correcting factor $)=0.54$ (Joergensen and Mueller, 1996). The soil total $\mathrm{C}$ and ${ }^{14} \mathrm{C}$ were measured using Carmograph $12 \mathrm{~A}$ (Wösthoff) and liquid scintillation counting (Bottner and Warembourg, 1976) and soil total $\mathrm{N}$ and ${ }^{15} \mathrm{~N}$ were measured using a coupled $\mathrm{CHN} /$ Mass spectrometer. At Patacamaya, only the soil total- $\mathrm{C},-{ }^{14} \mathrm{C}(4 \times 8$ replicates $)$, total-N and $-{ }^{15} \mathrm{~N}(4 \times 2$ replicates $)$ were analysed using the same procedure as at Gavidia. The MB was not analysed.

The biochemical analysis of the two straw types (Table 3) was performed according to van Soest et al. (1991). Plant material total- $\mathrm{C},-{ }^{14} \mathrm{C},-\mathrm{N}$ and $-{ }^{15} \mathrm{~N}$ were analysed using the same procedure as for the soil samples. The climatic data (at Gavidia: daily precipitation, maximum and minimum air temperature, and total radiation; at Patacamaya: the same data, in addition vapour pressure and mean wind speed) were automatically recorded (Campbell weather 
station) at the sites during the experimental period, except during a total of 3 months at Gavidia where the data were generated from climatic stations around the site and a total of 4 months at Patacamaya, where the data were randomly taken from records from previous years at the same site.

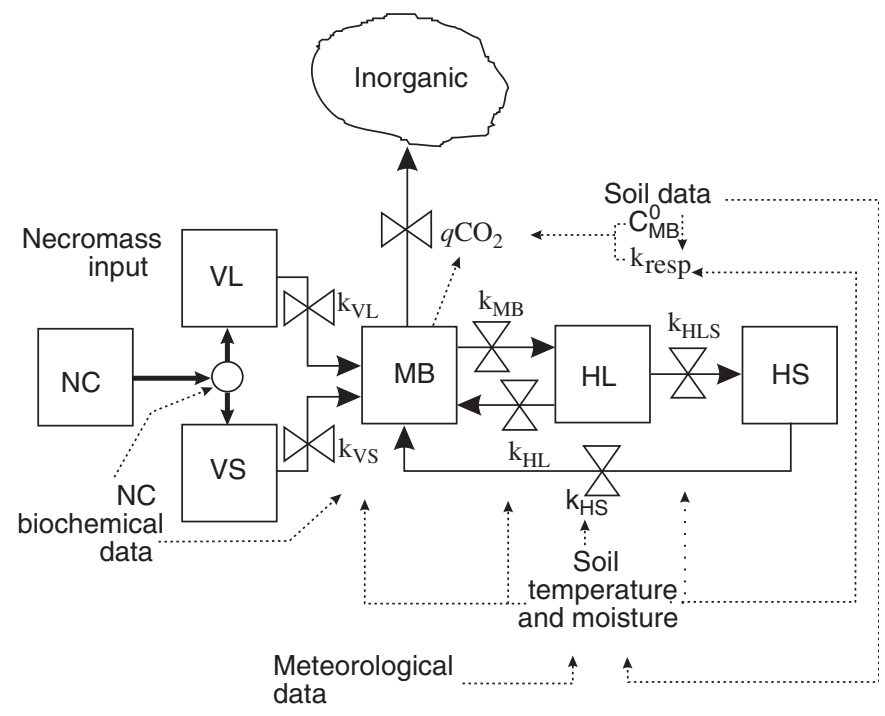

Fig. 1. Structure of the MOMOS-6 model (Pansu et al., 2004, 2006). $\mathrm{NC}=$ necromass $; \quad \mathrm{VL}=$ labile necromass $; \quad \mathrm{VS}=$ stable necromass; $\mathrm{MB}=$ microbial biomass; $\mathrm{HL}=$ labile humus; $\mathrm{HS}=$ stable humus; $\mathrm{C}_{\mathrm{MB}}^{0}=$ basal microbial biomass ${ }^{14} \mathrm{C} ; \mathrm{qCO}_{2}$ microbial metabolic quotient $\left(\mathrm{qCO}_{2^{-}}{ }^{14} \mathrm{C}=\mathrm{CO}_{2^{-}}{ }^{14} \mathrm{Cd}^{-1} \mathrm{MB}^{-14} \mathrm{C}^{-1}\right) ; k$ : kinetic constants, see Table 4.

\subsection{The MOMOS-6 decomposition model}

The model is described in detail and its accuracy and sensitivity are tested in Pansu et al. (2004, 2006). Briefly, five organic matter compartments are defined (Fig. 1 and Table 4): labile (VL) and stable (VS) plant material $(\mathrm{VL}+\mathrm{VS}=\mathrm{NC}=$ necromass $), \mathrm{MB}$, labile (HL) and stable (HS) humus. NC enters the soil and is partitioned into VL and VS, using the equations of Thuriès et al. (2002) which are based on the biochemical characteristics of $\mathrm{NC}$ presented in Table 3. VS accounted for $10.7 \%$ of NC for the $\mathrm{N}+$ plant material and for $14.4 \%$ for the $\mathrm{N}-$ material (Table 3). VL and VS provide the substrate for the MB which forms labile humus (HL) at death of the microorganisms. A small part of the HL matures to form stable humus (HS). Another part of HL and a small part of HS are reused as substrate for MB. Flows of matter are calculated using kinetic constants $(k$ constants, dimension day $^{-1}$, Table 4).

At the 9 samplings, the measurements required for the model were: total- ${ }^{14} \mathrm{C}$ and the total- ${ }^{14} \mathrm{C}:{ }^{15} \mathrm{~N}$ ratio, $\mathrm{MB}-{ }^{14} \mathrm{C}$ and the $\mathrm{MB}-{ }^{14} \mathrm{C}:{ }^{15} \mathrm{~N}$ ratio. $\mathrm{MB}-{ }^{14} \mathrm{C}$ measured at the last sampling was used as basal $\mathrm{MB}$ at steady state $\left(\mathrm{C}_{\mathrm{MB}}^{0}\right.$ in Table 4). The soil moisture in the $5-10 \mathrm{~cm}$ layer was predicted by the SAHEL model (Penning de Vries et al., 1989), using the water holding characteristics of the soils, the recorded daily climatic data and the soil moisture which was measured at each sampling occasion. All the kinetic constants were corrected by (1) an air temperature

Table 4

Parameters of the model

\begin{tabular}{|c|c|c|c|}
\hline Parameter & Estimated value & Explanation & \\
\hline$k_{\mathrm{HL}}$ & 0.05 & HL decrease rate (input of $B$ ) & \\
\hline$k_{\mathrm{HS}}$ & 0.00005 & HS decrease rate (input of B) & \\
\hline \multicolumn{4}{|c|}{ 2. Parameters linked to soil properties } \\
\hline$k_{\text {resp }}$ & $\operatorname{MAX}(0.127-0.0021 F, 0.01)$ & Microbial respiration rate & (1) \\
\hline \multicolumn{4}{|c|}{ 3. Parameters linked to the $C / N$ ratio of the plant material } \\
\hline$k_{\mathrm{MB}}$ & $\operatorname{MIN}\left(0.42+0.0012 \eta_{\mathrm{NC}}, 0.8\right)$ & MB mortality rate & (4) \\
\hline$k_{\mathrm{VL}}$ & $\operatorname{MAX}\left(0.65-0.0019 \eta_{\mathrm{NC}}, 0.1\right)$ & VL decrease rate (input of MB) & $(5)$ \\
\hline$k_{\mathrm{VS}}$ & $\operatorname{MAX}\left(0.0037-0.000026 \eta_{\mathrm{NC}}, 0.00005\right)$ & VS decrease rate (input of MB) & (6) \\
\hline \multicolumn{4}{|c|}{$C: N$ ratios of the compartments } \\
\hline MB & Measured data & \multicolumn{2}{|l|}{$\mathrm{C}: \mathrm{N}$ of microbial biomass } \\
\hline HL & $C_{\mathrm{HL}}:\left(\left(\mathrm{C}_{\mathrm{total}}: \eta_{\text {total }}\right)-\left(\mathrm{C}_{\mathrm{VL}}: \eta_{\mathrm{VL}}\right)-\left(\mathrm{C}_{\mathrm{Vs}}: \eta_{\mathrm{VS}}\right)-\left(\mathrm{C}_{\mathrm{MB}}: \eta_{\mathrm{MB}}\right)-\left(\mathrm{C}_{\mathrm{HS}}: \eta_{\mathrm{HS}}\right)\right)$ & \multicolumn{2}{|l|}{$\mathrm{C}: \mathrm{N}$ of labile humus } \\
\hline HS & $6 / 5$ of $\mathrm{C} / \mathrm{N}$ of the initial $[\mathrm{MB}]$ & \multicolumn{2}{|l|}{$\mathrm{C}: \mathrm{N}$ of stable humus } \\
\hline
\end{tabular}

$\eta={ }^{14} \mathrm{C}:{ }^{15} \mathrm{~N}$ ratios; $F=$ clay + silt content in $\% ; \mathrm{C}_{\text {total }}=$ total ${ }^{14} \mathrm{C} ; \eta_{\text {total }}=$ total ${ }^{14} \mathrm{C}$ :total ${ }^{15} \mathrm{~N} ; \mathrm{NC}=$ necromass; VL $=$ labile necromass; VS $=$ stable necromass; $\mathrm{MB}=$ microbial biomass; $\mathrm{C}_{\mathrm{MB}}^{0}=$ basal $\mathrm{MB}$ (at steady state); $\mathrm{HL}=$ labile humus; $\mathrm{HS}=$ stable humus; $f_{s}=$ stable fraction of the plant material, according Thuriès et al. (2002). 
function according to a power law with a coefficient $Q_{10}=2$, and with $20^{\circ} \mathrm{C}$ as optimal temperature (temperature correcting factor $=f(\mu)$, in range [0 1], Kätterer et al., 1998 ) and (2) a linear function of the ratio of soil moisture in the $5-10 \mathrm{~cm}$ layer and its moisture at field capacity (moisture correcting factor $=f(\theta)$, in range [0 1], Pansu et al., 2006).

\section{Results}

\subsection{Climatic conditions}

The two sites differ slightly in mean air temperature (Fig. 2B), but essentially in soil moisture (Fig. 2A). Gavidia is characterised by (1) long periods of moist soil, frequently close to field capacity (0.52), alternating with shorter dry periods and (2) small seasonal temperature amplitudes (during the period of experiment: generally between 7 and $11^{\circ} \mathrm{C}$ ). At Patacamaya (field capacity $=0.35$ ), the more sandy soil and drier climatic conditions generate long periods with the water content below the wilting point. The temperature is slightly colder, but with much higher seasonal amplitudes (between 1 and $14{ }^{\circ} \mathrm{C}$ ). The correcting factor temperature $\times$ soil moisture $(f(\theta) \times f(\mu))$ is relatively high at Gavidia, $(0.2-0.5)$ and lower at Patacamaya, $(0-0.5)$ with larger amplitudes (Fig. 2C). Thus Gavidia is warmer and markedly moister than Patacamaya.

\subsection{Fallow age}

At each site, the $\mathrm{N}+$ plant material was incubated in both the young and old fallow plots. At Gavidia the measured total- ${ }^{14} \mathrm{C}$, and $-{ }^{15} \mathrm{~N}$ values, (Figs. 3 and 4 ) and the measured $\mathrm{MB}-{ }^{14} \mathrm{C}$ and $-{ }^{15} \mathrm{~N}$ (Fig. 5) did not differ significantly between the two age plots. At Patacamaya the measured total- ${ }^{14} \mathrm{C}$ and $-{ }^{15} \mathrm{~N}$ contents were lower in the young plot compared to the old one during the first months and were comparable thereafter. At each site, the parameter values estimated using the model were statistically similar for the young and the old plots. Thus the fallow age did not significantly affect the predicted decomposition parameters. Consequently, for the modelling, data for $\mathrm{GaYN}+$ and $\mathrm{GaON}+$ were pooled in a single treatment called $\mathrm{GaN}+$. In the same way $\mathrm{PaYN}+$ and $\mathrm{PaON}+$ became $\mathrm{PaN}+$. Accordingly, in Table 2 only four treatments are finally presented: $\mathrm{GaN}+, \mathrm{GaN}_{-}$, $\mathrm{PaN}+$ and $\mathrm{PaN}-$

\subsection{Predicted and measured total $-{ }^{14} \mathrm{C}$, total $-{ }^{15} \mathrm{~N}$ and ${ }^{14} \mathrm{C}:{ }^{15} \mathrm{~N}$ ratio}

For the $\mathrm{N}$-rich plant material $(\mathrm{N}+$ treatment), the total- ${ }^{14} \mathrm{C}$ remaining at the end of the experiment was similar at both sites: $25 \%$ of the initial ${ }^{14} \mathrm{C}$ (Fig. 3). Both sites showed an initial active mineralisation phase followed by a lower activity phase. Nevertheless, the sites differed in their dynamics of total- ${ }^{14} \mathrm{C}$ : the fraction of ${ }^{14} \mathrm{C}$ mineralised during the initial phase was higher at Patacamaya than at Gavidia and inversely the fraction mineralised during the second phase was higher at Gavidia than at Patacamaya. For the N-poor plant material (N-treatment), at Gavidia, the total $-{ }^{14} \mathrm{C}$ mineralisation was significantly slower than that for $\mathrm{N}+$. The difference was essentially due to the slower decrease of ${ }^{14} \mathrm{C}$ of the $\mathrm{N}$ - material during the initial phase. At Patacamaya, the total- ${ }^{14} \mathrm{C}$ mineralisation of the $\mathrm{N}-$ material was also slower than for $\mathrm{N}+$; but the total- ${ }^{14} \mathrm{C}$ differences between the $\mathrm{N}+$ and $\mathrm{N}$ - treatments were smaller at Patacamaya than at Gavidia.

Total- ${ }^{15} \mathrm{~N}$ showed a tendency comparable to total- ${ }^{14} \mathrm{C}$ (Fig. 4). For $\mathrm{N}+$ and $\mathrm{N}-$, at Patacamaya the ${ }^{15} \mathrm{~N}$ mineralisation was faster and more complete $\left(\mathrm{Pa}{ }^{15} \mathrm{~N}+\right.$ remaining in the soil after $2 \mathrm{yr}=40 \%$ and $\mathrm{Pa}^{15} \mathrm{~N}-=60 \%$ of the initial $\left.{ }^{15} \mathrm{~N}\right)$ than at Gavidia $\left(\mathrm{Ga}^{15} \mathrm{~N}+\right.$ remaining $=65 \%$, Pa N- $=85 \%$ ). The difference between the two sites was essentially due to the initial phase. At both sites, the ${ }^{15} \mathrm{~N}$ mineralisation for the $\mathrm{N}-$ material was slower than for the $\mathrm{N}+$ material. At Gavidia, the plant material affected essentially the initial phase. After 180 days, the measured total- ${ }^{15} \mathrm{~N}$ values were almost parallel, whereas the predicted curves diverged slightly. At Patacamaya, the plant material affected the measured values essentially during the months 3 and 7. During the later phase, the decrease of the measured and predicted values was parallel. Thus, despite the lower Patacamaya climatic correcting factors (Fig. 2) the ${ }^{14} \mathrm{C}$ and ${ }^{15} \mathrm{~N}$ mineralisation process was more active at Patacamaya compared to Gavidia. The lower $\mathrm{N}$ content of the $\mathrm{N}-$ plant material hampered the ${ }^{15} \mathrm{~N}$ and ${ }^{14} \mathrm{C}$ mineralisation, but the differences between the $\mathrm{N}+$ and $\mathrm{N}-$ material were attenuated at Patacamaya, because of the higher mineralisation activity at this site for both kinds of material.

For both total- ${ }^{14} \mathrm{C}$ and $-{ }^{15} \mathrm{~N}$, the predictions are in accordance with the measured data $\left(R^{2}\right.$ generally above $0.9)$. Exceptions are the total- ${ }^{14} \mathrm{C}$ and $-{ }^{15} \mathrm{~N}$ in the GaNand $\mathrm{PaN}-$ treatments, which are overpredicted during the first five months at Gavidia (specially for ${ }^{15} \mathrm{~N}$, the model predicts no net ${ }^{15} \mathrm{~N}$ mineralisation during the 5 first months) and underpredicted at Patacamaya.

Fig. 4 also shows a similar evolution of the ${ }^{14} \mathrm{C}:{ }^{15} \mathrm{~N}$ ratios for $\mathrm{GaN}+$ and $\mathrm{PaN}+$ and for $\mathrm{GaN}-$ and $\mathrm{PaN}-$. The fast decrease of the ratios during the initial active phase $\left({ }^{14} \mathrm{C}:{ }^{15} \mathrm{~N}\right.$ ratios decreased from 130 to 85 for $\mathrm{GaN}-$ and $\mathrm{PaN}-$ and from 27 to 17 for $\mathrm{GaN}+$ and $\mathrm{PaN}+$ ) contrasted with the slow decrease (from 85 to 60 for $\mathrm{GaN}-$ and $\mathrm{PaN}-$ and from 17 to 12 for $\mathrm{GaN}+$ and $\mathrm{PaN}+$ ) during the subsequent long and less active phase. Thus the ratios also reflected the two-phase decomposition dynamics.

\subsection{Predicted and measured microbial biomass $-{ }^{14} \mathrm{C}$ $\left(M B-{ }^{14} \mathrm{C}\right)$ and $-{ }^{15} \mathrm{~N}\left(\mathrm{MB}-{ }^{15} \mathrm{~N}\right)$}

At both sites during the first 3 days, the predicted $\mathrm{MB}$ increased sharply, with $\mathrm{MB}-{ }^{14} \mathrm{C}$ reaching $20-30 \%$ of total $-{ }^{14} \mathrm{C}$, and for $\mathrm{MB}^{-15} \mathrm{~N}$ reaching $80 \%$ of total $-{ }^{15} \mathrm{~N}$ for 

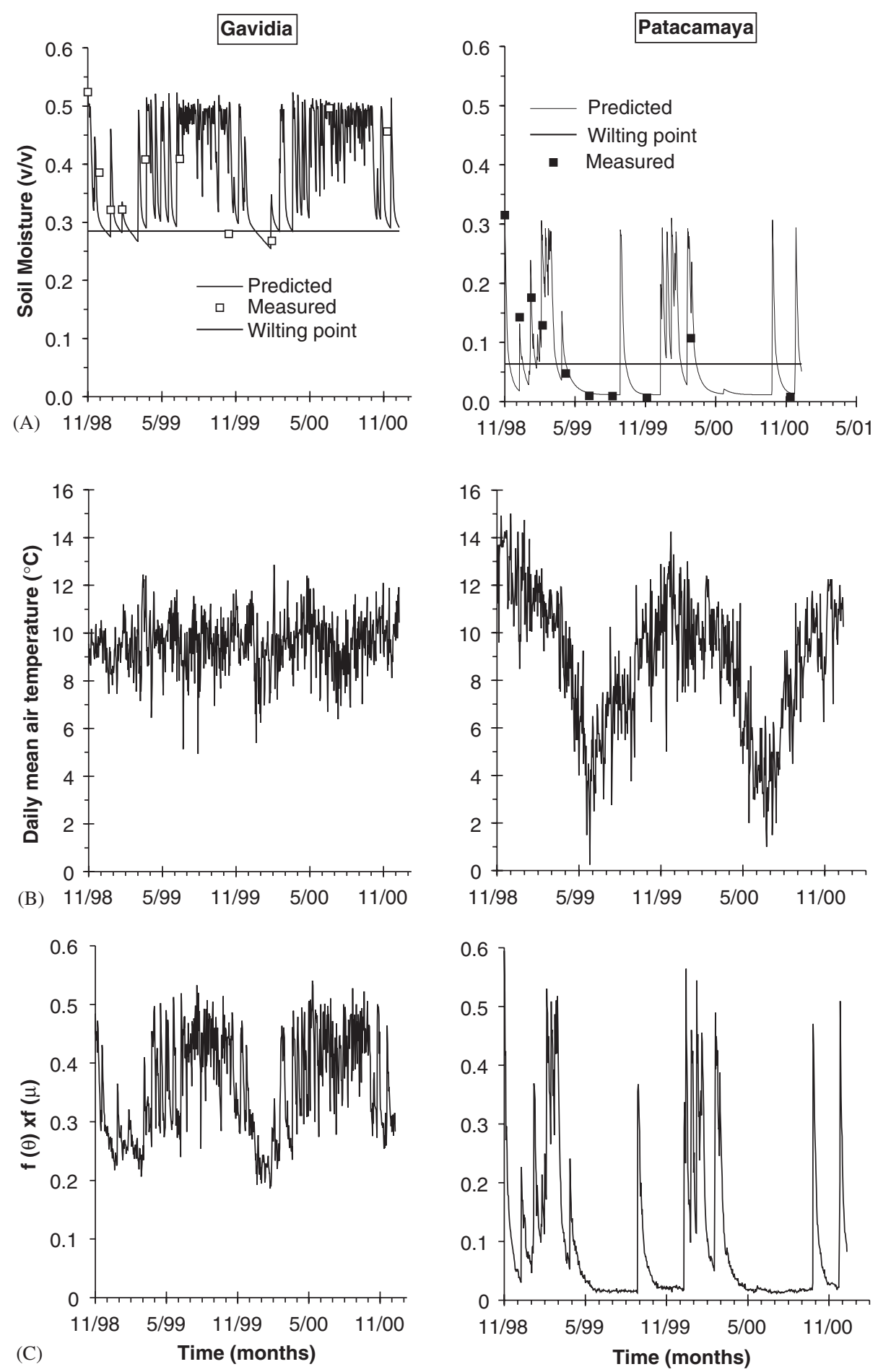

Fig. 2. Climatic data recorded and/or predicted during the time of experiment. (A) Predicted (SAHEL model) and measured moisture (mm/mm) in the 5-10 cm layer; (B) Recorded daily mean air temperature $\left({ }^{\circ} \mathrm{C}\right)$; (C) Temperature $\times$ soil moisture response function $($ correcting factor $=f(\theta) \times f(\mu))$. Gaps in climatic data record exceeding a duration of $10 \mathrm{~d}$ : Gavidia: 02/02-21/02/1999 and 15/11-03/12/1999; Patacamaya: 24/04-30/05/1999 and 30/10-30/11/ 1999.

all treatments (not visible in Fig. 5). Maybe a few amount of labelled biomass was still present in the labelled plant material. After this initial brief high peak, the predicted $\mathrm{MB}-{ }^{14} \mathrm{C}$ and $-{ }^{15} \mathrm{~N}$ decreased quickly, showing two activity phases, similar to the dynamics of total- ${ }^{14} \mathrm{C}$ and $-{ }^{15} \mathrm{~N}$ (Fig. 5).
At Gavidia, for the $\mathrm{N}+$ material, the $\mathrm{MB}-{ }^{14} \mathrm{C}$ and $-{ }^{15} \mathrm{~N}$ predictions adequately described the measured data over the $2 \mathrm{yr}$ of decomposition (in the young as well as the old fallow plots). MB- ${ }^{14} \mathrm{C}$ and $-{ }^{15} \mathrm{~N}$ expressed as a percentage of initial total- ${ }^{14} \mathrm{C}$ and $-{ }^{15} \mathrm{~N}$ predicted by the model were similar for the $\mathrm{N}+$ and $\mathrm{N}-$ treatments, i.e. the proportion 

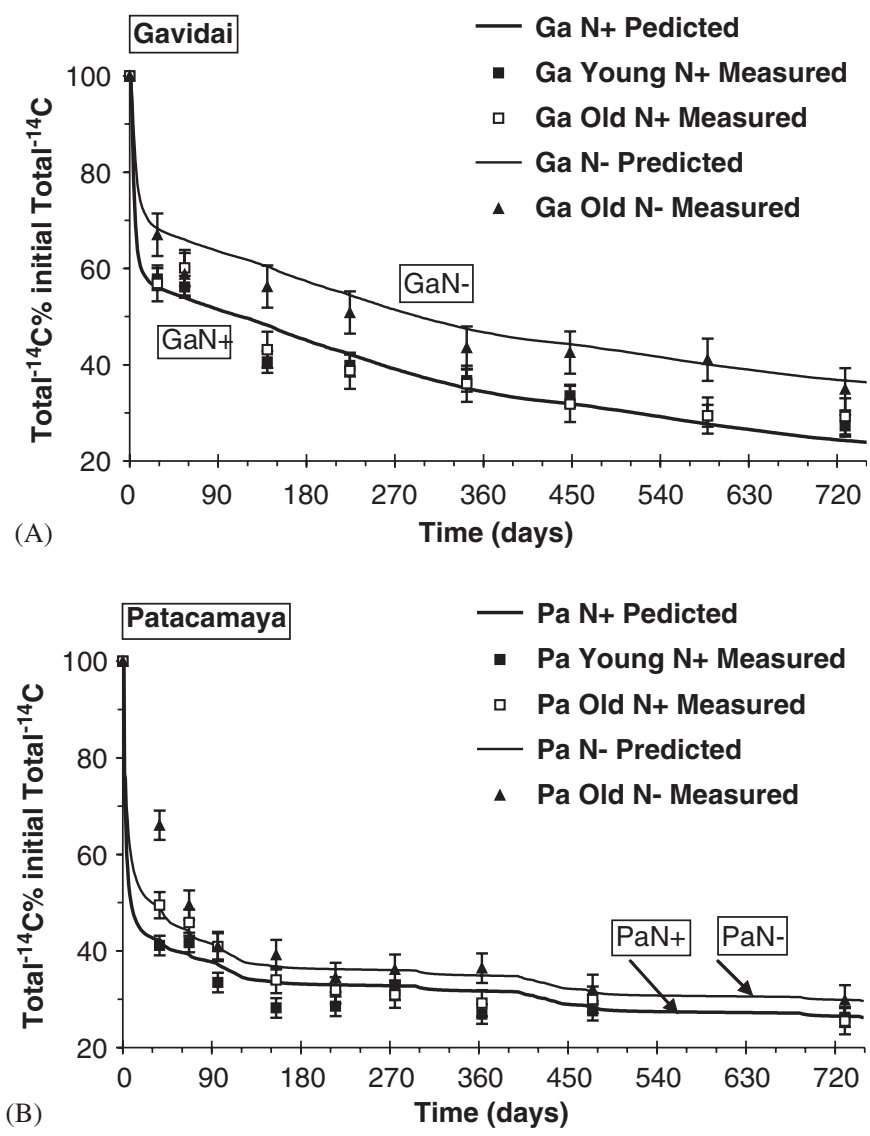

Fig. 3. Measured and predicted total- ${ }^{14} \mathrm{C}$ in $\%$ of initial total- ${ }^{14} \mathrm{C}$. $\mathrm{Ga}=$ Gavidia; $\mathrm{Pa}=$ Patacamaya; $\mathrm{N}+$ and $\mathrm{N}-=\mathrm{N}$-rich and $\mathrm{N}$-poor plant material; young $=2$-yr-old fallow; old $=7$-yr-old fallow; bars $=$ pooled standard deviation.

of ${ }^{14} \mathrm{C}$ and ${ }^{15} \mathrm{~N}$ in $\mathrm{MB}$ was independent of the $\mathrm{N}$ content of the plant material. At Gavidia for the $\mathrm{N}-$ material, the model overpredicted $\mathrm{MB}-{ }^{14} \mathrm{C}$ as well as $-{ }^{15} \mathrm{~N}$, during the 6 first months.

MB was not measured at Patacamaya. The model predicts $\mathrm{MB}-{ }^{14} \mathrm{C}$; but the prediction of $\mathrm{MB}-{ }^{15} \mathrm{~N}$ needs $\mathrm{MB}-{ }^{14} \mathrm{C}:{ }^{15} \mathrm{~N}$ measured data. Thus to predict $\mathrm{MB}^{15} \mathrm{~N}$ at Patacamaya, the $\mathrm{MB}-{ }^{14} \mathrm{C}:{ }^{15} \mathrm{~N}$ ratios measured at Gavidia (mean values, for $\mathrm{N}+: 8$, for $\mathrm{N}-:$ 33) were used. Similarly to the total- ${ }^{14} \mathrm{C}$, and $-{ }^{15} \mathrm{~N}$ dynamics, the decrease of the predicted $\mathrm{MB}-{ }^{14} \mathrm{C}$ and $-{ }^{15} \mathrm{~N}$ during the initial active phase was sharper in the Patacamaya soil than in the Gavidia soil. During the following phase of lower activity, the MB size predicted for Patacamaya quickly reached the basal level and remained relatively unchanged until the end of the experiment, while at Gavidia $\mathrm{MB}-{ }^{14} \mathrm{C}$ and $-{ }^{15} \mathrm{~N}$ continued to decrease slowly.

\subsection{Predicted labile humus $\left(H L-{ }^{14} \mathrm{C}\right.$ and $\left.-{ }^{15} \mathrm{~N}\right)$ and stable humus $\left(\mathrm{HS}-{ }^{14} \mathrm{C}\right.$ and $\left.-{ }^{15} \mathrm{~N}\right)$}

HL (Fig. 1) is a conceptual compartment for which no measured data are available. At Gavidia for both treatments, HL was the largest ${ }^{14} \mathrm{C}$ and ${ }^{15} \mathrm{~N}$ reservoir (Fig. 6), amounting to maximum values of $40(\mathrm{GaN}+)$ and $50 \%$ $(\mathrm{GaN}-)$ of the initial total- ${ }^{14} \mathrm{C}$ and to $70(\mathrm{GaN}+)$ and $90 \%(\mathrm{GaN}-)$ of the initial total- ${ }^{15} \mathrm{~N}$ (between months 1 and 2). At Patacamaya, HL amounted to up to $25 \%$ of the initial ${ }^{14} \mathrm{C}$ and to $45 \%$ of the initial ${ }^{15} \mathrm{~N}$ (between months 2 and 3) for $\mathrm{PaN}+$ and $\mathrm{PaN}-$. The ${ }^{14} \mathrm{C}:{ }^{15} \mathrm{~N}$ ratios of $\mathrm{HL}$ decreased with time from 80 to 50 for the $\mathrm{N}$ - treatments and from 20 to 10 for the $\mathrm{N}+$ treatments. These values are lower than the total- ${ }^{14} \mathrm{C} /$ total- $^{15} \mathrm{~N}$ ratios. At Gavidia, the model predicts higher $\mathrm{HL}-{ }^{14} \mathrm{C}$ and $\mathrm{HL}-{ }^{15} \mathrm{~N}$ proportions (in $\%$ of the initial $-{ }^{14} \mathrm{C}$ and $-{ }^{15} \mathrm{~N}$ ) for $\mathrm{N}-$ than for $\mathrm{N}+$; the maximum difference is $10 \%$ for ${ }^{14} \mathrm{C}$ and $20 \%$ for ${ }^{15} \mathrm{~N}$ (Fig. 6). At Patacamaya, the differences for $\mathrm{HL}_{-}{ }^{14} \mathrm{C}$ and $-{ }^{15} \mathrm{~N}$ between $\mathrm{PaN}+$ and $\mathrm{PaN}-$ were smaller. Thus the relative higher amount of total- ${ }^{14} \mathrm{C}$ and total- ${ }^{15} \mathrm{~N}$ which was observed in the $\mathrm{GaN}$ - treatment compared to $\mathrm{GaN}+$ (Figs. 3 and 4) is partly located in the HL compartment. The dominant HL reservoir is also demonstrated when its size is expressed relative to the remaining total $-{ }^{14} \mathrm{C}$ and $-{ }^{15} \mathrm{~N}$, (not presented in the figures): $\mathrm{HL}-{ }^{14} \mathrm{C}$ amounted to $75(\mathrm{GaN}+), 70(\mathrm{GaN}-), 60(\mathrm{PaN}+)$ and $50(\mathrm{PaN}-) \%$ of the remaining total- ${ }^{14} \mathrm{C}$.

The predicted (and not measured) HS compartment is not presented in the figures, as $\mathrm{HS}^{14}{ }^{14} \mathrm{C}\left(<3 \%\right.$ of initial ${ }^{14} \mathrm{C}$ for $\mathrm{Ga}$ and $<1 \%$ for Pa) and $\mathrm{HS}^{-{ }^{15} \mathrm{~N}}\left(<8 \%\right.$ of initial ${ }^{15} \mathrm{~N}$ for $\mathrm{Ga}$ and $<2 \%$ for $\mathrm{Pa}$ ) were negligible during the entire period of exposure.

\section{Discussion}

\subsection{Labelling experiment}

In the Gavidia treatments, the added straw-C ranged from $9.0 \%$ to $9.9 \%$ of sum of soil-C + straw-C mixture (Table 2), i.e. for the three Gavidia treatments, the amount of added straw was almost equal. But at Patacamaya, the straw-C added for the $\mathrm{PaN}-$ treatment $(26.0 \%)$ was almost double the one for $\mathrm{PaN}+(15.3 \%)$. This was because in the Patacamaya organic matter-poor soil, (soil native $C=0.45-0.55 \%$; Table 2 ), it was necessary to increase the amount of straw for the PaN- treatment, in order to obtain a reliable ${ }^{15} \mathrm{~N}$ spectrometric signal. Nevertheless the amounts added in the different treatments are always far below the threshold of $15 \mathrm{~g}$ straw $\mathrm{C} \mathrm{kg}^{-1}$ dry soil, suggested by Jenkinson (1977a), and above which the amount of added $\mathrm{C}$ affects the decomposition processes. For the whole experiment, the lowest measured ${ }^{15} \mathrm{~N}$ enrichment (at the last sampling time) was $0.204 \pm 0.019 \%$ (Table 2). Thus, owing to the two kinds of straw ${ }^{15} \mathrm{~N}$ enrichment $\left({ }^{15} \mathrm{~N}\right.$ enrichment $=9.88 \%$ for the $\mathrm{N}+$ material and $22.56 \%$ for $\mathrm{N}-$; Table 3 ), the initial ${ }^{15} \mathrm{~N}$ enrichments of the soil + straw mixture were high enough to get reliable ${ }^{15} \mathrm{~N}$ measurements for all treatments until the end of the experiment.

During the first months fine roots penetrated into the bags. On the basis of an ongoing ${ }^{15} \mathrm{~N}$ lysimetric study performed on potatoes crops at Gavidia (Sarmiento, 

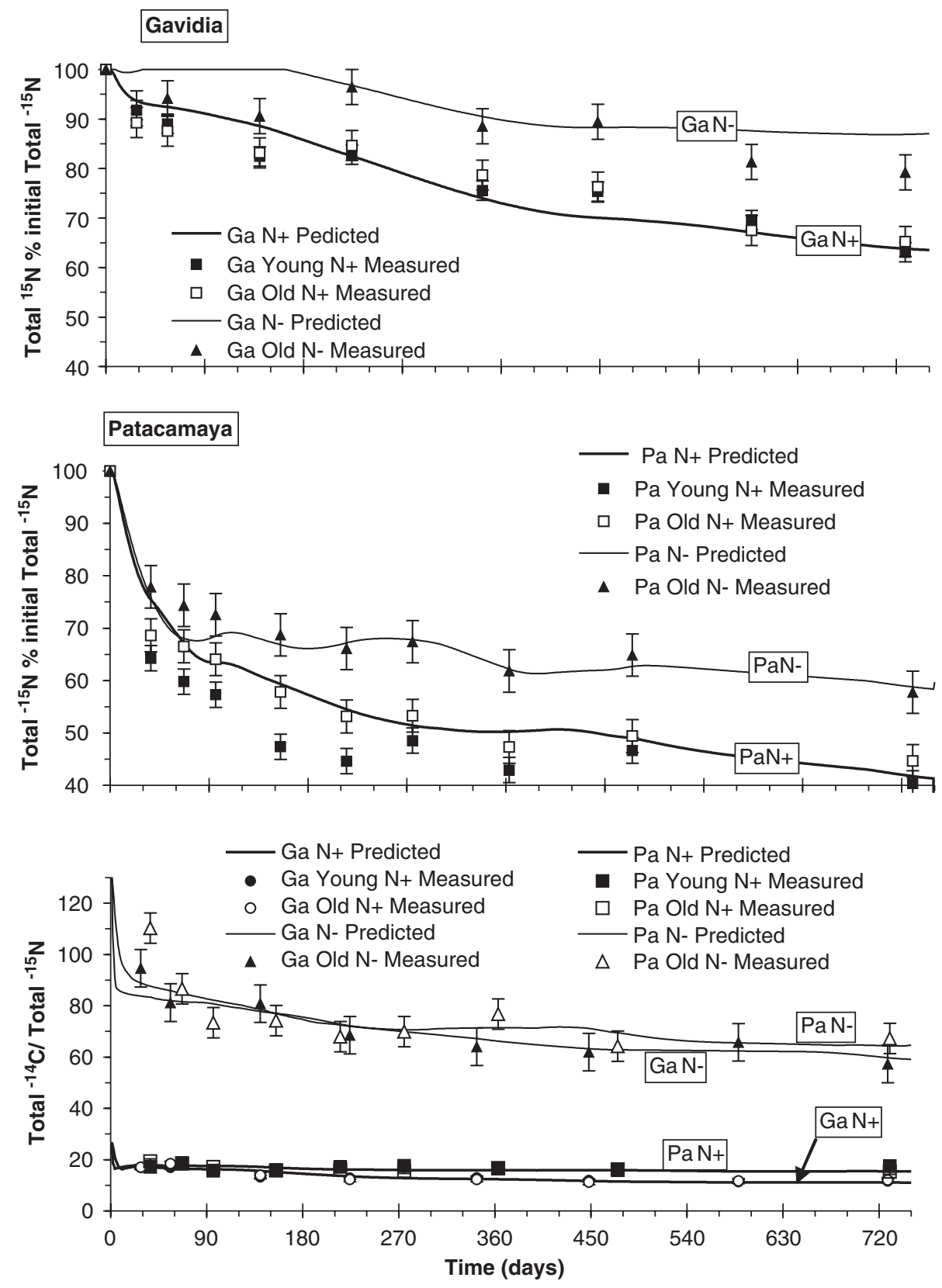

Fig. 4. Measured and predicted total- ${ }^{15} \mathrm{~N}$ in $\%$ of initial total- ${ }^{15} \mathrm{~N}$ and total- ${ }^{14} \mathrm{C}:$ total- ${ }^{15} \mathrm{~N}$ ratio. Ga $=$ Gavidia; $\mathrm{Pa}=\mathrm{Patacamaya} ; \mathrm{N}+$ and $\mathrm{N}-=\mathrm{N}-$ rich and N-poor plant material; young $=2$-yr-old fallow; old $=7$-yr-old fallow; bars = pooled standard deviation.

unpublished data), it is assumed that the ${ }^{15} \mathrm{~N}$ that was mineralised was quickly taken up by the growing plants; a smaller part was leached. If soluble organic ${ }^{15} \mathrm{~N}$ was leached, it was considered to be mineralised during the migration downwards. If ${ }^{15} \mathrm{~N}$ is lost in gaseous material, it was previously in inorganic form. Thus the decrease in the bags of total- ${ }^{14} \mathrm{c}$ and $-{ }^{15} \mathrm{~N}$ can by considered as resulting from mineralisation in the bags or during their migration downwards. However inorganic ${ }^{15} \mathrm{~N}$ is probably not completely used by the plants and thus the total $-{ }^{15} \mathrm{~N}$ measurements may underestimate the ${ }^{15} \mathrm{~N}$ mineralisation.

\subsection{Decomposition and fallow age}

The exposure of the $\mathrm{N}+$ material in 2 and $7 \mathrm{yr}$-old plots allowed to investigate the effect of the fallow age. At Gavidia, the measured data (total- ${ }^{14} \mathrm{C},-{ }^{15} \mathrm{~N}$ and $\mathrm{MB}-{ }^{14} \mathrm{C}$, $-{ }^{15} \mathrm{~N}$ ) were similar in the two plots. At Patacamaya, some samplings during the first months indicated a faster total- ${ }^{14} \mathrm{C}$ and $-{ }^{15} \mathrm{~N}$ mineralisation in the young fallow plot. Nevertheless at both sites, the age affected neither the predicted kinetic constants nor the predicted size of the compartments, indicating similar decomposition conditions. At both sites, an effect of fallow age on soil moisture 

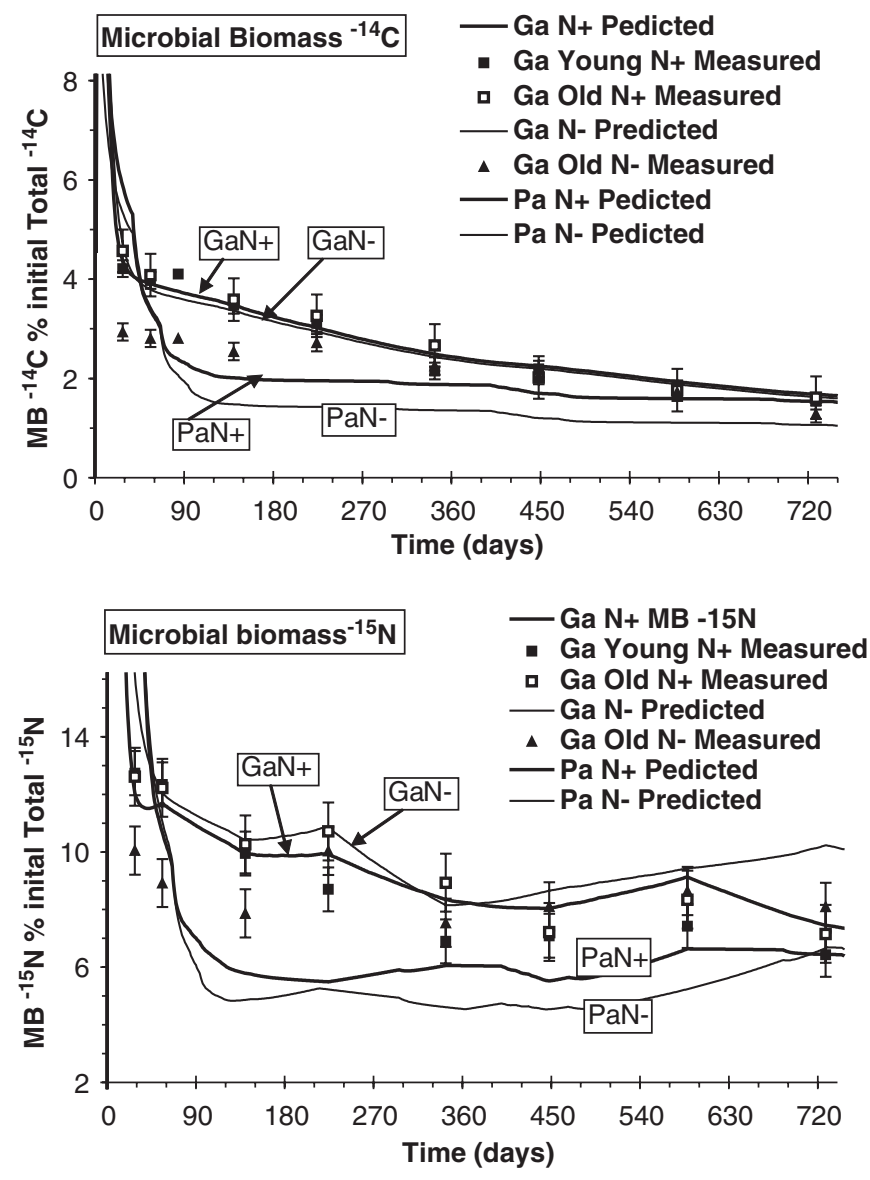

Fig. 5. Measured and predicted microbial biomass- ${ }^{14} \mathrm{C}\left(\mathrm{MB}-{ }^{14} \mathrm{C}\right)$ in $\%$ of initial total- ${ }^{14} \mathrm{C}$ and microbial biomass- ${ }^{15} \mathrm{~N}\left(\mathrm{MB}^{15} \mathrm{~N}\right)$ in $\%$ of initial total $-{ }^{15} \mathrm{~N}$. Ga $=$ Gavidia; $\mathrm{Pa}=$ Patacamaya; $\mathrm{N}+$ and $\mathrm{N}-=\mathrm{N}$-rich and $\mathrm{N}$-poor plant material; young $=2$-yr-old fallow; old $=7$-yr-old fallow; bars $=$ pooled standard deviation.

content (measured and simulated) was seldom significant. Thus the difference in evapotransiration due to the two stages of development of fallow vegetation did not modify the soil moisture in the upper layers and thus did not affect the decomposition kinetics. Abadín et al. (2002) analysed the $0-15 \mathrm{~cm}$ layer of 32 soil profiles at the site of Gavidia throughout a range of fallow ages from 0 to $8 \mathrm{y}$ and in the never cultivated Paramo. The $\mathrm{C}$ content ranged from 46 to $118 \mathrm{~g} \mathrm{~kg}^{-1}$ dry soil and $\mathrm{N}$ from 3.2 to $8.0 \mathrm{~g} \mathrm{~kg}^{-1}$, without significant correlation to the fallow age and independently from the geomorphologic situations. Also the water holding capacities were not significantly different. At Patacamaya the $\mathrm{C}$ content ranges from 2 to $10 \mathrm{~g} \mathrm{~kg}^{-1}$ dry soil, $\mathrm{N}$ from 0.4 to $1 \mathrm{~g} \mathrm{~kg}^{-1}$ and the $\mathrm{C}: \mathrm{N}$ ratios from 4 to 11 (data from the analyses of the $0-20 \mathrm{~cm}$ layer of 40 profiles of 1-20 yr-old fallow plots; Acea, pers. comm.; Hervé, 1994)). No significant age effect was observed. Thus fallow age does not affect the soil native total-C and $-\mathrm{N}$ content significantly neither at Gavidia nor at Patacamaya. Llambi and Sarmiento (1998) observed a high variability of the size of the MB over a range of $1-9 \mathrm{yr}$ of fallow ages at Gavidia, but there was no significant variation according to fallow age. Only the never cultivated Paramo showed a signifi- cantly higher biomass size. Similarly, in the present work, measured and predicted $\mathrm{MB}-{ }^{14} \mathrm{C}$ and $-{ }^{15} \mathrm{~N}$ were not affected by the fallow age in Gavidia. Martineau and Saugier (2006b) investigated the fallow productivity at Gavidia using the Fallow Productivity Model (FAPROM) and predicted an increasing production of biomass and necromass (NC) during the natural fallow successional development (i.e. with increasing fallow age). At the same Gavidia site, Sarmiento et al. (2003) observed an increasing diversification of the $\mathrm{NC}$ quality during the succession development. Nevertheless, the increasing NC production and its qualitative change measured and predicted by these authors is not followed by an increased amount of SOM nor by a modification of its quality as attested by the measurements of Abadín et al. (2002) and Llambi and Sarmiento (1998). This inconsistency is probably due to a problem of variability. In these mountains the extremely high soil variability (depth, stoniness, rooting zone, water flow, organic matter content, etc), due to the slope, landscape and geomorphologic heterogeneity, does not allow to detect a $\mathrm{C}$ or $\mathrm{N}$ variation as a response to vegetation succession and fallow age.

Using tracer techniques, the present work suggests that, in these wet or dry Andean fallow systems, the potential decomposition capacity, defined by the kinetic constants $(k)$, is independent of the fallow age. The decomposition capacity does neither increase during the soil restoration throughout the successional development (old fallow) nor decrease as a response of soil exhaustion by cultivation (young fallow). Under laboratory conditions, Sarmiento and Bottner (2002) observed only a slightly faster decomposition of ${ }^{14} \mathrm{C}$-labelled straw incubated in a $15 \mathrm{yr}$ fallow soil compared to a soil that had been cultivated for three consecutive years (decomposition rate was 0.045 and 0.041 , respectively). The cultivation-fallow system is probably accompanied by modifications in the actual microbial activity, as a response (1) to the exhaustion of nutrients and shortage of substrate supply during the crop period or (2) to the increasing supply of $\mathrm{NC}$ and to the increasing diversity of the quality of the NC during the long fallow period (Sarmiento et al., 2003). But, given the large species diversity and functional redundancy of the microbial population, and given the ability of microorganisms to survive in dormant forms under low energy supply, the decomposition potential is not altered under limiting substrate conditions. As suggested by Wardle and Giller (1996) the adequate functioning of the soil requires a number of species which is far below the one which occurs naturally. These conclusions are not surprising for the moist Paramo soils with a high organic matter content $(C=10 \%)$. But more surprisingly the dry and organic poor $(C=0.5 \%)$ Puna soils also show an unaltered decomposition capacity (no effect of fallow age). Owing to the fantastic plasticity of the soil biota, this raises the question if in these cultivation-fallow systems, the exhausted soils may loose their decomposition capacity, i.e. the ability to respond quickly to a substrate supply. These 

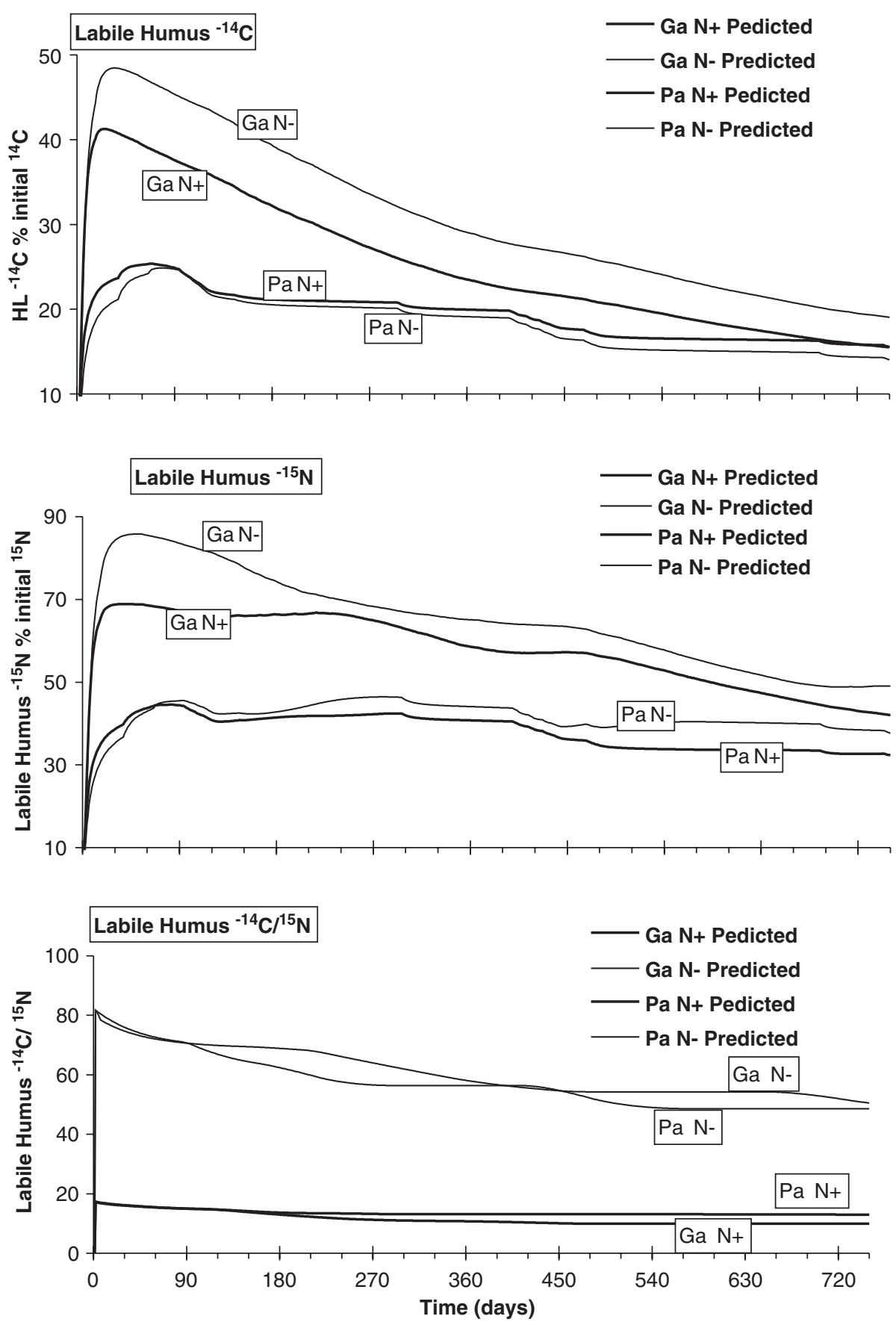

Fig. 6. Predicted labile humus- ${ }^{14} \mathrm{C}\left(\mathrm{HL}-{ }^{14} \mathrm{C}\right)$ and $-{ }^{15} \mathrm{~N}\left(\mathrm{HL}-{ }^{15} \mathrm{~N}\right)$ in $\%$ of initial total- ${ }^{14} \mathrm{C}$ and $-{ }^{15} \mathrm{~N}$. Labile humus ${ }^{14} \mathrm{C}:{ }^{15} \mathrm{~N}$ ratio. Ga $=\mathrm{Gavidia}$; $\mathrm{Pa}=$ Patacamaya; $\mathrm{N}+$ and $\mathrm{N}-=\mathrm{N}$-riche and $\mathrm{N}$-poor plant material.

mountain soils probably seldom reach such a threshold. Under completely different conditions, in West African sandy savannah soils (Senegal) with a low organic matter content, Manlay et al. (2002) also observed a relatively constant biological activity throughout a fallow chronosequence.

The lignin content of the labelled straw was $3 \%$ for $\mathrm{N}+$ and $6.4 \%$ for $\mathrm{N}-$. This is probably representative of the plant material of the young fallow which is essentially composed of herbs. The proportion of woody plants increases in the older fallow, with probably a higher lignin content. Nevertheless in these older vegetation types, we do not know the mean lignin content of the composite above and below ground annual litter production composed of shrub leafs and annually dying herbs.

\section{3. $C$ and $N$ flows: the decomposition processes}

Fig. 7A and $\mathrm{B}$ summarises the distribution (in cumulative form) of ${ }^{14} \mathrm{C}$ and ${ }^{15} \mathrm{~N}$ in the compartments for the 
Gavidia $\mathrm{N}+$ treatment $(\mathrm{GaN}+)$. At time $0, \mathrm{NC}$ represents $100 \%$ of initial ${ }^{14} \mathrm{C}$ and ${ }^{15} \mathrm{~N}$. The VL part (Fig. 1; not shown in Fig. 7; 89\% of NC, Table 3) disappears within a few weeks during the wet season of November 1998, with the temperature $\times$ moisture factor $>0.5$ (Fig. 2C) and this defines the active decomposition phase. After this time, the remaining $\mathrm{NC}$ is constituted exclusively from VS the stable plant material (Fig. 1; not shown in Fig. 7). The energy provided from the VL mineralisation enables to build up $\mathrm{MB}$ and the high microbial activity is shown by a high $q^{14} \mathrm{CO}_{2}$ level during this active phase (not shown), reflecting an overflow metabolism (Schimel and Weintraub, 2003). When VL is exhausted, MB declines sharply with an increasing storage of microbial cadavers and metabolites in HL. Due to the energy shortage the surviving organisms then become progressively dormant; the $q^{14} \mathrm{CO}_{2}$ values are divided by 5 (not shown). During the active microbial phase (when VL was the major substrate), the size of HL strongly increased and when the supply from VL becomes negligible (i.e. during the low activity phase), HL becomes the major reservoir and source of $\mathrm{C}$ and $\mathrm{N}$ for $\mathrm{MB}$. HL in its turn progressively declines when the supply as substrate for MB (HL output) exceeds the HL input from $\mathrm{MB}$ as cadavers and metabolites (Fig. 1). Thus during the low activity phase, that lasts almost over $5 / 6$ of the $2 \mathrm{yr}$ of exposure, the activity of the soil essentially consists in (re)cycling $\mathrm{C}$ and $\mathrm{N}$ between MB and HL. Both compartments progressively decline, providing the energy for the organisms. Although HS (the slow stabilisation of a small part of HL, Fig. 1) increased constantly, its contribution was not significant in this $2 \mathrm{yr}-$ long experiment. HS pool is a major reservoir in terms of global C cycling. But another methodology (based on soil native $\mathrm{C}$ and $\mathrm{N}$ and dating) is needed to predict its dynamics.

Given the model structure, the distribution of $\mathrm{N}$ is similar to C (Fig. 7B), with nevertheless a higher $\mathrm{N}$ storage in microbial cells (MB) and metabolites (HL) and a higher $\mathrm{N}$ immobilisation in $\mathrm{HS}$ (due to the low $\mathrm{C}: \mathrm{N}$ ratios in these compartments). At Gavidia with the $\mathrm{N}+$ material $(\mathrm{GaN}+)$, the initial NC-C:N was 27. During the active phase the major concentration of $\mathrm{N}$ occurred in $\mathrm{MB}$ (with MB-C:N mean value $=8$ ) and HL (with HL-C:N = 20). During the subsequent low activity phase i.e. during cycling of $\mathrm{C}$ and $\mathrm{N}$ between $\mathrm{MB}$ and HL, the HL C:N values decrease and approached progressively to the MB$\mathrm{C}: \mathrm{N}$ values. Thus as $\mathrm{HL}$ is the largest organic compartment with a low $\mathrm{C}: \mathrm{N}$ value, $\mathrm{HL}$ is also the reservoir providing directly or indirectly the major inorganic $\mathrm{N}$ for the plants and is after some weeks almost the only inorganic $\mathrm{N}$ source. The role of HL was experimentally explored by Jawson et al. (1989). They compared the mineralisation rates of ${ }^{14} \mathrm{C}$ - and ${ }^{15} \mathrm{~N}$-labelled wheat straw and of dead microbial cells and observed a preference by the microorganisms for the dead microbial material due to its lower $\mathrm{C}: \mathrm{N}$ values.
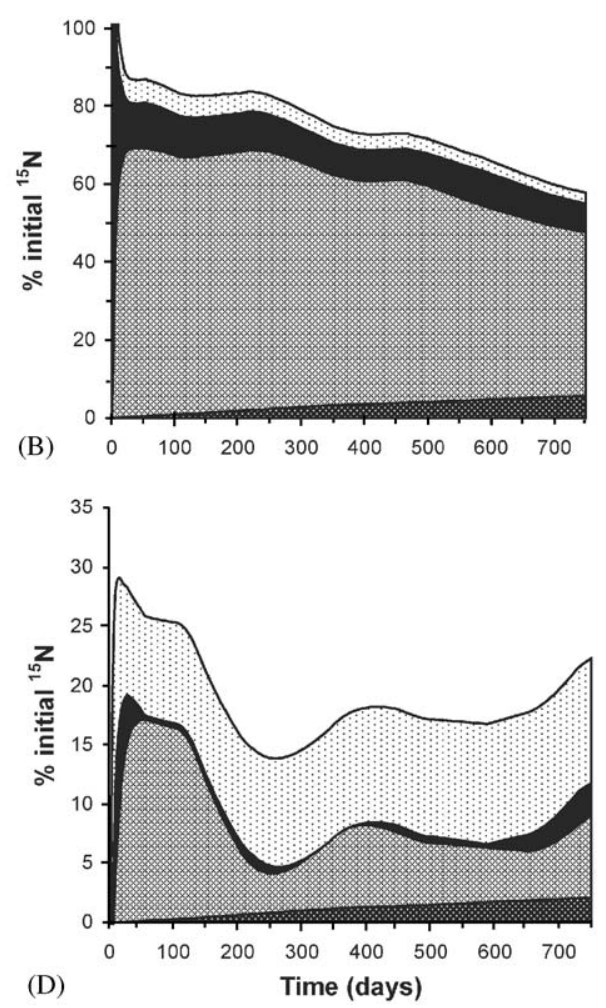

Fig. 7. Cumulative distribution of ${ }^{14} \mathrm{C}$ and ${ }^{15} \mathrm{~N}$ in each compartment in the Gavidia soil. (A) ${ }^{14} \mathrm{C}$ in $\%$ of initial total- ${ }^{14} \mathrm{C}$ for Gavidia $\mathrm{N}$-rich plant material $(\mathrm{GaN}+) ;(\mathrm{B}):{ }^{15} \mathrm{~N}$ in $\%$ of initial total $-{ }^{15} \mathrm{~N}$ for Gavidia N-rich plant material $(\mathrm{GaN}+)$; $(\mathrm{C}):\left({ }^{14} \mathrm{C}\right.$ in the compartments in $\%$ of initial ${ }^{14} \mathrm{C}$ for $\left.\mathrm{GaN}-\right)-\left({ }^{14} \mathrm{C}\right.$ in the compartiments in \% of initial ${ }^{14} \mathrm{C}$ for GaN +); (D): $\left({ }^{15} \mathrm{~N}\right.$ in the compartments in \% of initial ${ }^{15} \mathrm{~N}$ for GaN-) - $\left({ }^{15} \mathrm{~N}\right.$ in the compartments in $\%$ of initial ${ }^{15} \mathrm{~N}$ for $\mathrm{GaN}+$ ). 


\subsection{Carbon and nitrogen interactions: $N$-rich versus $N$-poor plant material}

In the labelling chamber the concentration of the nutrient solution used to grow the $\mathrm{N}$ - wheat was five times less concentrated than the one used for the $\mathrm{N}+$ wheat. In addition to the difference in $\mathrm{N}$ content, the plant material also differed by some biochemical properties, especially in the proportion of soluble compounds, cellulose and lignin (Table 3). Nevertheless, according to the equations of Thuriès et al. (2002) that are based on the biochemical characteristics of the plant material, the difference in the partitioning of the initial $\mathrm{NC}$ into labile (VL) and stable (VS) fractions was small $\left(\mathrm{VL}^{-14} \mathrm{C}=89.3 \%\right.$ and $85.6 \%$ of $\mathrm{NC}_{-}{ }^{14} \mathrm{C}$ for $\mathrm{N}+$ and $\mathrm{N}-$, respectively), but the lower VL:VS ratio significantly slowed down the predicted NC (Fig. 1) decomposition (not shown). However the model shows that the effect of the two kinds of plant material was essentially due to the different $\mathrm{N}$ contents.

The $\mathrm{N}-$ plant material compared to $\mathrm{N}+$ markedly reduced the total- ${ }^{15} \mathrm{~N}$ mineralisation: after 2 yr $12 \%$ versus $35 \%$ of the initial ${ }^{15} \mathrm{~N}$ was mineralised in the Gavidia soil and $40 \%$ versus $60 \%$ at Patacamaya (Fig. 4); but also the ${ }^{14} \mathrm{C}$ mineralisation was reduced (Fig. 3). The major difference occurred during the active decomposition phase. Essentially the NC and HL compartments were affected; but the MB was not affected. The question is to understand the $\mathrm{C}$ and $\mathrm{N}$ interaction processes. Christensen (1985) who buried barley straw with different $\mathrm{N}$ contents in soils also observed a higher weight loss for the $\mathrm{N}$ rich material but only during the first month after burial. Ocio et al. $(1991 \mathrm{a}, \mathrm{b})$ also observed that the biomass- $\mathrm{N}$ was only marginally affected when wheat straw was incorporated in the soil alone or with addition of $\mathrm{NH}_{4} \mathrm{NO}_{3}$.

The absolute amount of ${ }^{15} \mathrm{~N}$ remaining in the soil is smaller in the $\mathrm{N}-$ treatment than in $\mathrm{N}+$, since the $\mathrm{N}-$ initial ${ }^{15} \mathrm{~N}$ (the added straw $\mathrm{N}$ in Table 2) was much lower. But for $\mathrm{N}-$ the ${ }^{15} \mathrm{~N}$ remaining in the soil expressed in $\%$ of initial ${ }^{15} \mathrm{~N}$, is higher than for $\mathrm{N}+$. Thus the soil of the $\mathrm{N}-$ treatment retained a higher proportion of the initial ${ }^{15} \mathrm{~N}$ compared to $\mathrm{N}+$ and the distribution on the different compartments is also different. Fig. 7C and D presents, for Gavidia, the distribution (in cumulative form) of the predicted relative extra amount of ${ }^{14} \mathrm{C}$ and ${ }^{15} \mathrm{~N}$ which is retained in the $\mathrm{GaN}-$ treatment and expressed in \% of the initial ${ }^{14} \mathrm{C}$ and ${ }^{15} \mathrm{~N}$, i.e. Fig. $7 \mathrm{C}$ represents: $\left({ }^{14} \mathrm{C}\right.$ in the compartments in $\%$ of initial ${ }^{14} \mathrm{C}$ for $\left.\mathrm{GaN}-\right)-\left({ }^{14} \mathrm{C}\right.$ in the compartments in $\%$ of initial ${ }^{14} \mathrm{C}$ for $\mathrm{GaN}+$ ) and Fig. 7D represents: $\left({ }^{15} \mathrm{~N}\right.$ in the compartments in $\%$ of initial ${ }^{15} \mathrm{~N}$ for $\mathrm{GaN}-)-\left({ }^{15} \mathrm{~N}\right.$ in the compartments in $\%$ of initial ${ }^{15} \mathrm{~N}$ for $\mathrm{GaN}+$ ). In other words, Fig. $7 \mathrm{C}$ and $\mathrm{D}$ present the relative extra amount of total- $-{ }^{14} \mathrm{C}$ and $-{ }^{15} \mathrm{~N}$ in $\%$ of initial, that is mineralised from soil supplied with $\mathrm{N}$-rich plant material or alternatively the relative amount of ${ }^{14} \mathrm{C}$ and ${ }^{15} \mathrm{~N}$ in \% of initial, that is retained in the soil supplied with $\mathrm{N}$-poor material. When a soil is supplied with plant material with a high $\mathrm{C} / \mathrm{N}$ ratio, a higher proportion of $\mathrm{N}$ is retained in the soil. Two major compartments are affected: the carbon is retained in (1) the NC (Fig. 7C), specially the stable NC (VS not shown), whose relative accumulation increases with time and in (2) HL, whose relative amount decreases with time. The contribution of the HS is minor and the ${ }^{14} \mathrm{C}$ of the predicted MB is not affected. The distribution of the relative extra amount of ${ }^{15} \mathrm{~N}$ is comparable to ${ }^{14} \mathrm{C}$, except for $\mathrm{MB}^{15} \mathrm{~N}$, but the difference between $\mathrm{MB}^{15} \mathrm{~N}$ in $\mathrm{GaN}+$ and $\mathrm{GaN}-$ was generally lower than $2 \%$. The smaller importance of $\mathrm{NC}-{ }^{15} \mathrm{~N}$ compared to $\mathrm{NC}-{ }^{14} \mathrm{C}$ is due to the difference of the $\mathrm{C}: \mathrm{N}$ ratios of the two kinds of added straw.

The results suggest two processes to explain the effect of the initial plant material C:N

(1) When the plant material $\mathrm{C}: \mathrm{N}$ ratio increased, the model reduced the mineralisation rates of $\mathrm{VL}\left(k_{\mathrm{VL}}\right)$ and of VS $\left(k_{\mathrm{VS}}\right)$, according to Eqs. (5) and (6) in Table 4, giving $k_{\mathrm{VL}}=0.6$ and 0.4 and $k_{\mathrm{VS}}=0.003$ and 0.0003 for $\mathrm{N}+$ $(\mathrm{NC}-\mathrm{C}: \mathrm{N}=27)$ and $\mathrm{N}-(\mathrm{NC}-\mathrm{C}: \mathrm{N}=130)$ respectively. Thus the restricted $\mathrm{N}$ supply may reduce the ability of the microorganisms to mineralise the NC. During the initial active phase, the measured and predicted slower mineralisation of total- ${ }^{14} \mathrm{C}$ and $-{ }^{15} \mathrm{~N}$ for $\mathrm{N}$ - compared to $\mathrm{N}+$ (Figs. 3 and 4 ) is explained by the lower amount of $\mathrm{VL}$ in $\mathrm{N}-(85.6 \%$, Table 3$)$ compared to $\mathrm{N}+$ $(89.3 \%)$ and essentially by the lower $k_{\mathrm{VL}}$ value for $\mathrm{N}-$. For both sites, the major difference between $\mathrm{N}+$ and $\mathrm{N}$ - treatments results from a difference in $k_{\mathrm{VL}}$. During the following low activity phase, when VL was exhausted, the N- VS material also decreased slower than the N+VS material (not shown), resulting from lower $k_{\mathrm{VS}}$ values for $\mathrm{N}-$ than for $\mathrm{N}+$. But this effect is minor compared to $k_{\mathrm{VL}}$. Thus the $\mathrm{C}: \mathrm{N}$ effect is more pronounced for $\mathrm{VL}$ than for $\mathrm{VS}$, despite a higher difference between $k_{\mathrm{VS}} \mathrm{N}+$ and $k_{\mathrm{VS}} \mathrm{N}-$ than between $k_{\mathrm{VL}} \mathrm{N}+$ and $k_{\mathrm{VL}} \mathrm{N}-$, because the $k_{\mathrm{VL}}$ values are much higher than the $k_{\mathrm{VS}}$ values.

(2) The other mechanism controlled by the NC-C:N results in an increased mortality of the microorganisms (MB) in response to an increased NC-C:N ratio $\left(\mathrm{k}_{\mathrm{MB}}\right.$, Eq. (4) in Table 4): with NC-C:N $=27$ for the $\mathrm{N}+$ material, $k_{\mathrm{MB}}=0.45$ and with $\mathrm{C}: \mathrm{N}=130$ for $\mathrm{N}-, k_{\mathrm{MB}}=0.58$. Thus, with a restricted $\mathrm{N}$ supply, the $\mathrm{C}$ and $\mathrm{N}$ flow from $\mathrm{MB}$ to $\mathrm{HL}$ is increased (Fig. 1). The parameter estimation did not modify the values of $k_{\mathrm{HL}}, k_{\mathrm{HLS}}$, or $k_{\mathrm{HS}}$ (Table 4, Fig. 1). Thus the increased flow from MB to $\mathrm{HL}$ for $\mathrm{N}-$ compared to $\mathrm{N}+$ enables to describe the sequestration of $\mathrm{C}$ and $\mathrm{N}$ in HL (Fig. 7C and D). In biological terms, in an $\mathrm{N}$ deficient situation $(\mathrm{N}-)$, the model describes an increased mortality of the microorganisms and an increased accumulation of $\mathrm{C}$ and $\mathrm{N}$ as microbial cadavers and metabolites. This process is active during the active decomposition phase. Thereafter, the progressive decrease of the extra-amount of HL observed in Fig. 7C and D indicates the recycling of 
microbial cadavers and metabolites by new populations, hence stimulating the turnover of $\mathrm{C}$ and $\mathrm{N}$ though MB and HL. Thus combining both effects (1 and 2), at the end of the $2 \mathrm{yr}$ of exposure, the effect 2 was overlapped by effect 1 and in Fig. 7C and D, the accumulation in the $\mathrm{N}$ - treatment of recalcitrant plant material (VS) predominated.

The predicted microbial respiration parameter $\left(k_{\text {resp }}\right.$ parameter in Table 4) was not modified in response to the NC-C:N variation. At Gavidia, the predicted $\mathrm{MB}-{ }^{14} \mathrm{C}$ and $-{ }^{15} \mathrm{~N}$ were only slightly modified by the NC-C:N ratio (Fig. 5). Nevertheless, the three first measured values of $\mathrm{MB}-{ }^{14} \mathrm{C}$ as well as $\mathrm{MB}-{ }^{15} \mathrm{~N}$ were significantly lower for the $\mathrm{N}-$ treatment than for $\mathrm{N}+$. Thus the probable inaccurate description of the MB dynamics during the first months may indicate that $k_{\text {resp }}$ may have been affected by the C:N ratio. At Patacamaya the predicted $\mathrm{MB}-{ }^{14} \mathrm{C}$ and ${ }^{15} \mathrm{~N}$ values for $\mathrm{N}-$ were also a little lower compared to $\mathrm{N}+$. But at this site, $\mathrm{MB}$ was not measured and this conclusion remains debatable.

Eq. (4)-(6) in Table 4 were calculated from two points (treatments $\mathrm{N}+$ and $\mathrm{N}-$ ), necessarily resulting in linear relations. The response functions to the $\mathrm{C}: \mathrm{N}$ variation are probably not simple linear functions. For generalisation of the model, the parameter $k_{\mathrm{MB}}$ is limited to a maximum value of 0.8 and $k_{\mathrm{VL}}$ to a minimum value of 0.1 ; but these limits have to be improved.

\subsection{Effects of abiotic soil properties}

The climatic temperature $\times$ moisture factor (Fig. 2C) was more favourable to decomposition at Gavidia than at Patacamaya. Nevertheless the total $-{ }^{14} \mathrm{C}$ and $-{ }^{15} \mathrm{~N}$ mineralisation was faster at Patacamaya than at Gavidia. We hypothesise that the climatic effect is dominated by the effect of soil properties. Three hypotheses have been explored:

(1) At Patacamaya the decomposition is accelerated as the soil is essentially sandy (Table 1). In contrast to the clay-loamy Gavidia soil, the organic matter at Patacamaya is not protected because of the lack of clay and loam minerals. Since Sorensen (1972) the effect of clay minerals on organic matter decomposition has been thoroughly investigated (Jenkinson, 1977b; Ladd et al., 1992). The microbial processes largely occur at the particle surfaces (Robert and Chenu, 1992); thus the microorganisms and the microbial decay products are both influenced by the quality of the mineral environment. Saggar et al. $(1996,1999)$ incubated ${ }^{14}$ C-labelled glucose and rye grass in grassland soils containing clays in varying amounts and from the major mineralogical classes. The authors showed that the stabilisation of the labelled organic matter is dependent upon the surface areas rather than upon the amount of clay. They calculated the mean residence time of organic matter, using a simple three-compartment model (substrate, $\mathrm{MB}$ and humus) and concluded that the clay surface had a larger protecting effect on the MB and microbial metabolites than on the humus compartment.

(2) At Gavidia, under the moist Paramo conditions, the massive microstructure linked to the high organic matter content $(C=10 \%)$, slows the decomposition down by hindering air circulation and oxygen supply. In contrast, in the Patacamaya $(C=0.5 \%)$ sandy environment, the high macroporosity allows a perfect aeration of the soil. The clay + silt content is $46 \%$ at Gavidia and $21 \%$ at Patacamaya. The sandy properties of the Patacamaya soil is a local characteristic linked to the sediments in this part of the Central Altiplano. In contrast, at Gavidia, according to Poulenard et al. (2003), the poorly aerated soil structure due to the combined effect of large organic matter content and moist mountain regime seems to be a regional widespread characteristic of the Paramo soils in the high altitude moist tropical Andean belt (specially Venezuela, Colombia and Ecuador). According to the authors, in these soils (developed on allophanic but also nonallophanic material), with a $\mathrm{C}$ pool up to $45 \mathrm{~kg} \mathrm{~m}^{-2}$ distributed over a depth of $50 \mathrm{~cm}$ and a fluffy (dry soil) and massive (moist soil) structure, the organic colloids built up voids with radii smaller than $0.1 \mu \mathrm{m}$. This prevents aeration and access of the microorganisms to the substrate (Sollins et al., 1996). The unusual high water content at field capacity (0.52) and at wilting point (0.28) at Gavidia indicates the predominance of ultra-fine porosity.

(3) The Gavidia soil has a high content of free aluminium that partly inhibits the microbial activity. The high content of $\mathrm{Al}$ hydroxides together with soil acidity also is a rather widespread regional characteristic of moist mountain temperate and tropical soils, when acid rock parent material (like schist at Gavidia or slate) weathers and $\mathrm{Al}^{3+}$ ions enter the soil solution. At Gavidia, the exchangeable $\mathrm{Al}^{3+}$ is $11.0 \pm 2.2 \mathrm{cmol} \mathrm{kg}^{-1} \mathrm{~d}$. s. and the free $\mathrm{Al}_{2} \mathrm{O}_{3}$ content is $25.5 \pm 6.0 \mathrm{~g} \mathrm{~kg}^{-1}$ d. s. (Abadín et al., 2002). Thus the free aluminium oxides largely surpass the threshold of $10 \mathrm{~g} \mathrm{~kg}^{-1}$ d. s., starting at which Gonzalez-Prieto et al. (1996) found a significant decrease of the net mineralisation rate of N. Martin and Haider (1986), Carballas et al. (1978) and Miltner and Zech (1998) observed a slower decomposition of the bulk organic matter and of specific compounds such as sugars, polysaccharides or phenols in the presence of ferrihydrites and Al hydroxides. The inhibition of decomposition was ascribed to chemical stabilisation processes by organo-mineral bounding, to the insolubilisation of the organic compounds and/or to the toxicity effect of $\mathrm{Al}$ hydroxides for microorganisms.

The difference between Gavidia and Patacamaya is described in the model by modifying only one parameter: the microbial respiration $\left(k_{\text {resp }}\right.$, Fig. 1$)=0.083$ at 
Patacamaya to 0.030 at Gavidia. The difference is important. In the case of the particle size hypothesis (hypothesis 1 ), the relationships between $k_{\text {resp }}$ and the silt + clay content is expressed by Eq. (1) in Table 4 (again a linear function based on only two points). Thus our result may support the conclusion of Saggar et al. (1999), that the particle size effect results from a protection of $\mathrm{MB}$ and its metabolites rather than from adsorption of humified compounds on the clay surfaces, as the effect is achieved by microbial respiration only, and as $k_{\mathrm{HL}}, k_{\mathrm{HLS}}$ and $k_{\mathrm{HS}}$ (Fig. 1) are apparently not changed. Indeed, as also observed by Ladd et al. (1995), the largest difference between the sandy (Patacamaya) and the clay-loamy (Gavidia) soil occurs during the phase of high biological activity (Figs. 3 and 5). The effect of soil properties on microbial activity is also attested by higher values of $q^{14} \mathrm{CO}_{2}$ at Patacamaya compared to Gavidia (not shown), indicating a lower demand for maintenance energy in the Gavidia soil where the biomass is located in a protected microenvironment.

The final conclusion is that the effect of soil properties lead to contrasting mechanisms. At Patacamaya there is no soil-related hindrance to decomposition. The essential control is played by the substrate quality (for instance $\mathrm{N}$ content of the NC) and the climatic conditions. At Gavidia, the decomposition may be retarded by the unfavourable microstructure or the Al toxicity, but the microorganisms are protected by the clay environment, allowing a higher fraction of biomass to survive with lower maintenance energy.

\subsection{Conclusion}

This work was executed at two contrasting tropical high Andean sites with different soil properties and climatic conditions and using contrasting substrate qualities. The soils are representative of the moist Paramo and dry Puna ecosystems which cover widespread areas in the upper elevation belt of agriculture. The aim was to describe the $\mathrm{C}$ and $\mathrm{N}$ transfers in the organic matter system. Four major conclusions emerge: (1) The same model allowed to describe the contrasting situations and treatments, indicating similar organic matter functioning processes governed by parameters specific to soil properties and substrate quality. (2) The fallow age does not alter the decomposition potential (the kinetic parameters), in other words the decomposition dynamics of the necromass ( $\mathrm{NC}$ ) entering the soil is not affected by the exhaustion or restoration state of the soil in the cultivation-fallow system. (3) The response of the soil system to the $\mathrm{N}$ content of the $\mathrm{NC}$ can be described modifying two sets of parameters: with an increased NC C:N ratio (a) the decomposition of the labile and stable plant material is lowered, resulting in lower total-C and $-\mathrm{N}$ mineralisation and (b) the mortality of the microbial biomass (MB) is increased, i.e. the production of microbial cadavers and metabolites and their recycling by new populations is accelerated. (4) The effect of climate is overlapped by the effect of soil properties. The data showed and, despite the climate correcting factors, the model described a faster decomposition in the dry Puna than in the moist Paramo. This is largely confirmed at a regional scale by the contrasting organic matter contents in the two ecosystems (total- $\mathrm{C}$ and $-\mathrm{N}$ contents are lower in the dry Puna than in the wet Paramo in a proportion of about $1-10$ ) and that the ecosystem productivity alone cannot explain. Owing to the climatic and parent material conditions, the Paramo soils are frequently characterised by (a) a massive microstructure restricting the oxygen supply and the access of microorganisms to substrate, and (b) an acid environment leading to an accumulation of aluminium hydroxides. Both regional abiotic characteristics in addition to the clay-loamy soil texture may lower the microbial activity and explain the organic matter accumulation in Paramo.

The implication of the organic matter pool in fertility management of the Andean agriculture, as corner stone of erosion control in mountain soils, as a large regional reservoir of $\mathrm{C}$ in the global cycling and the situation of the soils as headwaters areas of catchments controlling densely populated valleys, justified to improve our knowledge.

\section{Acknowledgements}

This work was supported by the TROPANDES INCOCD programme of the European Union (ERBIC 18CT980263). We are grateful to T. Carballas (CSIC-HAG, Santiago-de-Compostela, Spain), coordinator of the program, to A. Oliva (ICAE-ULA, Merida, Venezuela) for her help in the field experiment, to B. Buatois (CEFE-CNRS, Montpellier, France) and N. Marquez (ICAE-ULA, Merida, Venezuela) for the laboratory analyses.

\section{References}

Abadín, J., González-Prieto, S.J., Sarmiento, L., Villar, M.C., Carballas, T., 2002. Successional dynamics of soil characteristics in a long fallow agricultural system of the high tropical Andes. Soil Biology \& Biochemistry 34, 1739-1748.

Bottner, P., Warembourg, F., 1976. Method for simultaneous measurement of total and radioactive carbon in soils, soil extracts and plant materials. Plant and Soil 45, 273-277.

Brookes, P.C., Landman, A., Pruden, G., Jenkinson, D.S., 1985. Chloroform fumigation and the release of soil nitrogen: a rapid direct extraction method to measure microbial biomass nitrogen in soil. Soil Biology \& Biochemistry 17, 837-842.

Carballas, T., Carballas, M., Jacquin, F., 1978. Biodégradation et humification de la matière organique des sols humifères atlantiques. Anales de Edafologia y Agrobiologia 37, 205-212.

Christensen, B.T., 1985. Wheat and barley straw decomposition under field conditions: effect of soil type and plant cover on weight loss, nitrogen and potassium content. Soil Biology \& Biochemistry 17, 691-697.

Gonzalez-Prieto, S.J., Cabaneiro, A., Villar, M.C., Carballas, M., Carballas, T., 1996. Effect of soil characteristics on $\mathrm{N}$ mineralization capacity in 112 native and agricultural soils. Biology and Fertility of Soils 22, 252-260.

Hervé, D., 1994. Respuestas de los componentes de la fertilidad del suelo a la duracion del descanso. In: Hervé, D., Genin, D., Rivière, G. (Eds.), 
Dinamicas del descanso de la tierra en los Andes. IRD (ex-Orstom), Paris, La Paz, pp. 155-170.

Hofstede, R., Coppus, R., Mena-Vásconez, P., Segarra, P., Wolf, J., Sevink, J., 2002. El estado de conservación de los páramos de pajonal en el Ecuador. Ecotropicos 15, 3-18.

Jawson, M.D., Elliott, L.F., Papendick, R.I., Campbell, G.S., 1989. The decomposition of ${ }^{14} \mathrm{C}$-labeled wheat straw and ${ }^{15} \mathrm{~N}$-labeled microbial material. Soil Biology \& Biochemistry 21, 417-422.

Jenkinson, D.S., 1977a. Studies on the decomposition of plant material in soil. IV. The effect of rate of addition. Journal of Soil Science 28, 417-423.

Jenkinson, D.S., 1977b. Studies on the decomposition of plant material in soil. V. The effects of plant cover and soil type on the loss of carbon from ${ }^{14} \mathrm{C}$ labelled ryegrass decomposing under field conditions. Journal of Soil Science 28, 424-434.

Joergensen, R.G., 1996. The fumigation-extraction method to estimate soil microbial biomass: calibration of the $k(\mathrm{EC})$ value. Soil Biology \& Biochemistry 28, 25-31.

Joergensen, R.G., Mueller, T., 1996. The fumigation-extraction method to estimate soil microbial biomass: calibration of the $k(\mathrm{EN})$ value. Soil Biology \& Biochemistry 28, 33-37.

Kätterer, T., Reichstein, M., Andrén, O., Lomander, A., 1998. Temperature dependence of organic matter decomposition: a critical review using literature data analyzed with different models. Biology and Fertility of Soils 27, 258-262.

Ladd, J.N., Jocteur-Monrozier, L., Amato, M., 1992. Carbon turn-over and nitrogen transformation in an alfisol and vertisol amended with $\left[\mathrm{U}^{14} \mathrm{C}\right]$ glucose and $\left[{ }^{15} \mathrm{~N}\right]$ ammonium sulfate. Soil Biology \& Biochemistry 24, 359-371.

Ladd, J.N., Amato, M., Grace, P.R., van Veen, J.A., 1995. Simulation of C-14 turnover through the microbial biomass in soils incubated with C-14-labelled plant residues. Soil Biology \& Biochemistry 27, 777-783.

Llambi, L.D., Sarmiento, L., 1998. Biomasa microbiana y otros parametros edaficos en una sucesion secondaria de los Paramos Venezolanos. Ecotropicos 11, 1-14.

Manlay, R.J., Masse, D., Chotte, J.L., Feller, C., Kairé, M., Fardoux, J., Pontanier, R., 2002. Carbon, nitrogen and phosphorus allocation in agro-ecosystems of a West African Savannah: II. The soil component under semi-permanent cultivation. Agriculture, Ecosystems \& Environment 88, 233-248.

Martin, J.P., Haider, K., 1986. Influence of mineral colloids in turn-over rates of soil organic carbon. In: Huang, P.M., Schnitzer, M. (Eds.), Interactions of Soil Minerals with Organics and Microbes. Soil Science Society of America, Madison, WI, pp. 283-304.

Martineau, Y., Saugier, B., 2006a. Comportement contre-intuitif d'un modèle mécaniste de succession végétale. Comptes Rendus à l'Accademie des Sciences Paris (Serie biologie) 329, 21-30.

Martineau, Y., Saugier, B., 2006b. A process-based model of old-field succession linking ecosystem and community ecology, Ecological Modelling, submitted

Miltner, A., Zech, W., 1998. Carbohydrate decomposition in beech litter as influenced by aluminium, iron and manganese oxides. Soil Biology \& Biochemistry 30, 1-7.

Norton, J.M., Firestone, M.K., 1996. N dynamics in the rhizosphere of Pinus ponderosa seedlings. Soil Biology \& Biochemistry 28, 351-362.
Ocio, J.A., Brookes, P.C., Jenkinson, D.S., 1991a. Field incorporation of straw and its effects on soil microbial biomass and soil inorganic $\mathrm{N}$. Soil Biology \& Biochemistry 23, 171-176.

Ocio, J.A., Martinez, J., Brookes, P.C., 1991b. Contribution of strawderived $\mathrm{N}$ to total microbial biomass $\mathrm{N}$ following incorporation of cereal straw to soil. Soil Biology \& Biochemistry 23, 655-659.

Pansu, M., Bottner, P., Sarmiento, L., Metselaar, K., 2004. Comparison of five soil organic matter decomposition models using data from a ${ }^{14} \mathrm{C}$ and ${ }^{15} \mathrm{~N}$ labelling field experiment. Global Biogeochemical Cycles 18, GB4022.

Pansu, M., Sarmiento, L., Metselaar, K., Hervé, D., Bottner, P., 2006. Modelling the transformation and sequestration of soil organic matter in two contrasting ecosystems of the Andes. European Journal of Soil Science, accepted.

Penning de Vries, F.W.T., Jansen, D.M., ten Berge, H.F.M., Bakema, A., 1989. Simulation of Ecophysiological Processes of Growth in Several Annual Crops. Pudoc, Wageningen, 271p.

Poulenard, J., Podwojewski, P., Herbillon, A.J., 2003. Characteristics of non-allophanic Andisols with hydric properties from the Ecuadorian Paramos. Geoderma 117, 1-15.

Robert, M., Chenu, C., 1992. Interactions between soil minerals and microorganisms. In: Bollag, J.M., Stotzky, G. (Eds.), Soil Biochemistry, vol. 7. Marcel Dekker, New-York, pp. 307-404.

Saggar, S., Parshotam, A., Sparling, G.P., Feltham, C.W., Hart, P.B.S., 1996. ${ }^{14} \mathrm{C}$-labelled ryegrass turnover and residence times in soils varying in clay content and mineralogy. Soil Biology \& Biochemistry 28, 1677-1686.

Saggar, S., Parshotam, A., Hedley, C., Salt, G., 1999. ${ }^{14}$ C-labelled glucose turnover in New Zealand soils. Soil Biology \& Biochemistry 31, 2025-2037.

Sarmiento, L., 2000. Water balance and soil loss under long fallow agriculture in the Venezuelan Andes. Mountain Research and Development 20, 246-253.

Sarmiento, L., Bottner, P., 2002. Carbon and nitrogen dynamics in two soils with different fallow times in the high tropical Andes: indications for fertility restoration. Applied Soil Ecology 553, 1-11.

Sarmiento, L., Llambí, L.D., Escalona, A., Marquez, N., 2003. Vegetation patterns, regeneration rates and divergence in an old-field succession of the high tropical Andes. Plant Ecology 166, 145-156.

Schimel, J.P., Weintraub, M.N., 2003. The implications of exoenzyme activity on microbial carbon. and nitrogen limitation in soil: a theoretical model. Soil Biology \& Biochemistry 35, 549-563.

Sollins, P., Homann, P., Caldwell, B.A., 1996. Stabilization and destabilization of soil organic matter: mechanisms and controls. Geoderma 74, 65-105.

Sorensen, L.H., 1972. Stabilisation of newly formed amino-acids metabolites in soil by clay minerals. Soil Science 114, 121-130.

Thuriès, L., Pansu, M., Larré-Larrouy, M.C., Feller, C., 2002. Biochemical composition and mineralization kinetics of organic inputs in a sandy soil. Soil Biology \& Biochemistry 34, 239-250.

van Soest, P.J., Robertson, J.B., Lewis, B.A., 1991. Symposium: carbohydrate methodology, metabolism, and nutritional implications in dairy cattle. Journal of Dairy Science 74, 3583-3597.

Wardle, D.A., Giller, K.E., 1996. The quest for a contemporary ecological dimension to soil biology. Soil Biology \& Biochemistry 28, 1549-1554. 